\title{
ANALISA PEMBANGUNAN MANUSIA DAN PENGARUHNYA TERHADAP KESEJAHTERAAN MASYARAKAT DI PROVINSI PAPUA
}

\author{
Charley M. Bisai \\ charleybisai@feb.uncen.ac.id \\ Maria Kbarek \\ kbarekmaria@gmail.com \\ Achmad Riyadi Pajeru \\ achmadriyadipajeru@gmail.com
}

\begin{abstract}
Abstrak
Human development in Papua is still a central issue and is a concern of the government at the national and regional levels. If human development is in its actual position, it will have an impact on the welfare of its people. Human development uses the HDI indicator (Human Development Index) while the welfare of the community uses indicators of income per capita and poverty. Some of the objectives to be achieved from this study include to analyze: (1.) the correlation of the forming components with HDI; (2.) what components form the largest HDI; and (3.) the effect of HDI on income per capita, and poverty. This study uses secondary data with the analysis period 2010 - 2018. Data analysis was performed using correlation and regression analysis techniques. The analysis shows that: (1) All components of $\mathrm{HDI}$ are positively and significantly related to HDI. The AHH component has a strong relationship, while the other components are very strong. The HLS and RLS components (education index) have the greatest magnitude of the correlation coefficient so they form the dominant $\mathrm{HDI}$ compared to $\mathrm{AHH}$ and Per capita Expenditures. (2) $\mathrm{HDI}$ has a positive and significant effect on per capita income in Papua Province. (3). HDI has a negative and significant effect on poverty levels in Papua Province.
\end{abstract}

\section{PENDAHULUAN}

Hakikat pembangunan manusia diawali dengan pemahaman wacana konsep pekerjaan. Pada dasarnya, adanya pekerjaan akan memberi rasa kondusif secara ekonomi. Pekerjaan memberi kontribusi bagi meningkatnya pertumbuhan ekonomi, pemberantasan kemiskinan, serta kesetaraan gender. Di lain sisi, adanya pekerjaan bisa dimanifestasikan sebagai bentuk kepedulian terhadap sesama dalam membangun keterikatan diantara keluarga, komunitas, dan masyarakat.

Dalam arti yang lebih luas, pekerjaan tidak lagi sekedar upaya untuk meningkatkan kekayaan fisik/ekonomi, namun juga memperluas pengetahuan; sehingga pada kesannya membentuk nilai budaya dan peradaban. Intinya, pekerjaan membuat potensi, kreativitas, dan semangat manusia. Dari pemahaman tersebut bisa ditarik benang-merah bahwa tujuan 
pembangunan manusia tidaklah semata-mata untuk meningkatkan pendapatan, tetapi juga memberi peluang seluas-luasnya kepada individu dalam memenuhi hak asasinya, memilih pilihan dengan bebas, membuatkan kemampuan dan peluang berkarya, serta mempunyai kehidupan yang kreatif dan sehat dalam jangka waktu yang panjang.

Termasuk di dalam kategori negara berkembang, Indonesia memiliki masalah pembangunan manusia yang sangat menarik dan unik untuk diteliti. Pembangunan manusia mendapat tempat yang krusial dalam pembangunan ekonomi karena menyangkut kualitas dan kuantitas manusia sehingga perlu dicermati secara mendalam. Ada tiga (3) alasan mendasar yang menjadi acuan dalam menguliti masalah pembangunan manusia. Pertama, beberapa negara berkembang dapat mencapai pertumbuhan ekonomi tinggi, gagal mengatasi kesenjangan sosial, ekonomi dan kemiskinan. Kedua, negara-negara dengan pendapatan rendah sukses mencapai tingkat pembangunan manusia yang tinggi karena, secara bijaksana menggunakan semua sumber daya (modal, manusia, alam) yang dimilikinya untuk mengembangkan kemampuan dasar manusia. Ketiga, negaranegara maju di dunia dengan tingkat pendapatan tinggi yang, tidak mampu mengatasi atau menutaskan masalah-masalah sosial yang muncul didalam masyarakatnya (Ginting dkk, 2008).

Michael Todaro (dalam Baeti, 2013), mendefinisikan bahwa pembangunan adalah upaya atau proses untuk melakukan sejumlah perubahan ke arah yang lebih baik. Kegiatan pembangunan mencakup segala bentuk perubahan pada berbagai aspek sosial, politik, ekonomi, dan budaya, oleh karenanya pembangunan merupakan syarat yang mutlak dalam menjamin kelangsungan suatu negara. Keberhasilan pembangunan ekonomi tercermin dari beberapa nilai dasar atau nilai inti yang terdiri dari ; kecukupan (sustenance), jati diri (self-estreem), dan kebebasan (freedom), harus tercapai pada setiap masyarakat dan individu sebagai tujuan utama. Kecukupan mengandung arti bahwa masyarakat secara mandiri dapat memenuhi segala kebutuhan pokok hidupnya seperti ; sandang, pangan, dan papan. Dimana kebutuhan-kebutuhan tersebut sangat diperlukan masyarakat dalam menunjang kehidupannya. 
Pembangunan manusia hingga kini masih menjadi isu sentral dan universal selama keberadaan atau eksistensi manusia belum punah di atas muka bumi. Kompleksitas persoalan dan keberagaman tatanan kehidupan manusia menyebabkan persolan ini memiliki karakteristiknya tersendiri berdasarkan aspek ruang (wilayah) dan waktu. Situasi ini menyebabkan Indonesia menempatkan isu pembangunan manusia didalam kerangka perencanaan pembangunan di tingkat nasional seperti di dalam RPJMN hingga pada level daerah atau provinsi dan kabupten/kota yang diakomodir dalam RPJMD.

Publikasi BPS pada tahun 2017 menunjukkan bahwa, pencapaian pembangunan manusia (IPM) di Indonesia pada tingkat provinsi cukup bervariasi. Angka IPM di tingkat provinsi berkisar antara 59,09 hingga 80,06 dimana tertinggi pada DKI Jakarta dan terendah di Papua. Pada dimensi umur panjang dan hidup sehat, tercermin melalui Umur Harapan Hidup saat lahir antara 64,34 tahun di Sulawesi Barat sedangkan 74,74 tahun di Yogyakarta. Sementara itu, pada dimensi pengetahuan, Harapan Lama Sekolah berada antara 10,54 tahun di Papua dan 15,42 tahun di Yogyakarta, serta Rata-rata Lama Sekolah penduduk usia 25 tahun, terendah 6,27 tahun di Papua dan tertinggi 11,02 tahun di DKI Jakarta. Pengeluaran per kapita di tingkat provinsi terendah sebesar Rp. 7,0 juta rupiah pertahun terjadi di Papua dan tertinggi sebesar Rp. 17,7 juta rupiah pertahun di DKI Jakarta (BPS Indonesia, 2018).

Kondisi faktual pembangunan manusia tersebut di atas memberikan gambaran bahwa Provinsi Papua merupakan salah satu provinsi di Indonesia yang masih memiliki persolan yang cukup berat dan menjadi tantangan dan satu sisi menjadi tanggungjawab semua pihak dalam hal penanganannya. Sejak menjadi bagian dari NKRI pada tanggal 1 Mei 1963, pemerintah telah berupaya semaksimal mungkin untuk melaksanakan kegiatan pembangunan di Provinsi Papua. Dalam kurun waktu 56 tahun hingga saat ini, pemerintah telah menerapkan sejumlah kebijakan dan strategi untuk membangun Provinsi Papua, termasuk pemberian Otonomi Khusus (Otsus) yang seluas-luasnya namun belum mampu mensejajarkan Papua dengan provinsi atau daerah lainnya di Indonesia. 
Analisis penelitian LIPI yang dipimpin Widjojo Muridan S. (2008) dalam "Papua Roadmap" menyebutkan bahwa terdapat empat faktor penyebab konflik serta penyebab utama kegagalan pembangunan di Papua. Pertama, persoalan marjinalisasi serta perlakuan diskriminatif terhadap Orang Asli Papua (OAP) akibat pembangunan ekonomi, konflik politik, dan migrasi massal (tranmigrasi) ke Papua sejak 1970. Kedua, pemerintah gagal melakukan konsolidasi pembangunan pada bidang pendidikan, kesehatan dan pemberdayaan ekonomi kerakyatan. Ketiga, pelurusan sejarah serta pengakuan terhadap identitas politik orang Papua. Keempat, tanggungjawab moral pemerintah atas kekerasan di masa lampau terhadap warga negara Indonesia di Papua (HAM).

Kenyataannya, memang berbagai indikator kesejahteraan masyarakat dan indikator keberhasilan pembangunan di Provinsi Papua menunjukkan gambaran yang cenderung membaik namun masih ada gap dengan daerah lainnya di Indonesia yang cukup besar. Publikasi BPS Papua (2018), menunjukkan bahwa rata -rata persentase penduduk miskin di Provinsi Papua sejak tahun 2010 hingga 2018 sebesar 30,32 persen, bahkan sebagian besar kabupaten masih diatas 30 persen. Jumlah penduduk miskin di Provinsi Papua pada tahun 2010 sebesar 981.200 jiwa hingga tahun 2018 turun menjadi 917.630 jiwa, terdapat penurunan jumlah penduduk sebesar 63,570 jiwa kurun waktu tersebut. Hingga tahun 2018 terdapat 4 (empat) kabupaten dengan jumlah penduduk paling tinggi di Provinsi Papua berada di Kabupaten Jayawijaya sebanyak 82.900 jiwa, Yahukimo 74.020 jiwa, Lanny Jaya 71.080 jiwa, Paniai 64.450 jiwa.

Publikasi BPS juga menunjukkan bahwa pada tahun 2010 pendapatan perkapita di Provinsi Papua sebesar Rp. 38,79 juta per tahun lebih tinggi dibanding Indonesia sebesar Rp. 30,76 juta, hingga tahun 2018 pendapatan perkapita Provinsi Papua telah mencapai Rp. 63,40 juta sedangkan Indonesia sebesar Rp. 59,80 juta. Walaupun memiliki pendapatan perkapita lebih tinggi dari Provinsi Papua namun situasi ini belum sepenuhnya menjamin terwujudnya kesejahteraan masyarakat di Provinsi Papua.

Berdasarkan uraian - uraian diatas maka peneliti berupaya untuk mengangkat isu pokok dalam penelitian atau tulisan ini tentang bagaimana kualitas pembangunan manusia 
dan pengaruhnya terhadap tingkat kesejahteraan penduduk atau masyarakat di Provinsi Papua kurun waktu 2010- 2018.

\section{LANDASAN TEORI DAN PENGEMBANGAN HIPOTESIS}

\section{PARADIGMA PEMBANGUNAN MANUSIA}

Pembangunan manusia, menurut UNDP, didefinisikan sebagai suatu proses yang ditujukan untuk memperluas alternatif bagi penduduk (people). Dalam konsep ini, penduduk (manusia) ditempatkan sebagai tujuan akhir (the ultimate end) dalam rangka pembangunan itu sendiri serta sebagai sarana utama (principal means) dalam rangka mencapai tujuan itu.

Paradigma pembangunan manusia melihat bahwa usaha dalam rangka peningkatan kualitas manusia mengadung nilai intrinsik, dalam arti, sebagai tujuan pada dirinya sendiri. Prespektif ini berbeda dengan pembangunan sumberdaya manusia, yang berupaya menempatkan manusia sebagai sumber atau input pembangunan serta melihat kualitas manusia sebagai sarana (means) penghasil pendapatan. Dalam paradigma pembangunan yang holistik, pembangunan manusia mensyaratkan kebijakan pembangunan yang programkan, seharusnya bercirikan "of, for and by people". Maksud dari ciri-ciri ini adalah sebagai berikut: Pertama, tentang penduduk (of people), yakni pemberdayaan penduduk yang diupayakan melalui investasi bidang-bidang pendidikan kesehatan, dan pelayanan sosial dasar lainnya; kedua, untuk penduduk (for people), yakni pemberdayaan penduduk yang diupayakan melalui penciptaan peluang kerja dan perluasan peluang berusaha (dengan cara memperluas kegiatan ekonomi suatu wilayah); ketiga, oleh penduduk (by people), yakni pemberdayaan penduduk yang dapat menaikan derajat, harkat dan martabat melalui partisipasi dalam pengambilan keputusan di segala bidang. Agar tujuan tersebut dapat tercapai maka, empat hal pokok yang perlu diperhatikan, yaitu: produktivitas, pemerataan, kesinambungan, dan pemberdayaan. Dimana empat hal ini saling berkait, dan menjadi faktor penentu dalam merumuskan kebijakan pembangunan manusia (dalam arti yang luas). 
Konsep dasar pembangunan manusia tersebut lebih luas jika dibandingkan dengan teori-teori pembangunan ekonomi konvensional termasuk di dalamnya pendekatan pertumbuhan ekonomi, pembangunan sumberdaya manusia (SDM), pendekatan kesejahteraan, dan pendekatan kebutuhan-kebutuhan dasar manusia. Dalam Model pertumbuhan ekonomi selalu berkaitan dengan upaya peningkatan pendapatan dan produksi nasional (GNP). Pembangunan SDM, terutama menempatkan manusia sebagai masukan (input) dari proses produksi sebagai suatu sarana saja dan bukan sebagai tujuan. Pendekatan kesejahteraan memposisikan manusia sebagai penerima manfaat dan tidak sebagai "agen" perubahan pembangunan. Pendekatan kebutuhan dasar terfokus pada penyediaan barang dan jasa untuk kebutuhan hidup manusia.

\section{KEBIJAKAN PEMBANGUNAN MANUSIA}

Pemahaman yang mendalam terhadap konsep pembangunan manusia seutuhnya, sangat penting bagi para perencana pembangunan untuk dalam melihat persoalan dan kebutuhan pembangunan secara komprehensif atau menyeluruh, sehingga dapat menghasilkan kebijakan yang tepat dalam rangka pembangunan manusia di daerah. Kebijakan yang tepat terhadap pembangunan manusia harus dilihat secara integral sehingga tersusun mulai dari proses analisis pembangunan manusia, hingga impliksinya dan strategi intervensi dan kebutuhan program-program yang berwawasan pembangunan manusia.

Sesuai dengan konsep global pembangunan manusia sebagaimana diuraikan di depan, maka kebijakan pembangunan manusia dapat diuraikan sebagai berikut:

Pertama, kebijakan pembangunan manusia haruslah diarahkan pada upaya:

1) Meningkatkan produktivitas. Manusia atau individu harus ditingkatkan kemampuannya untuk dapat secara kreatif dan mandiri menciptakan pekerjaan, dan atau sumbersumber pendapatan yang menunjangnya untuk dapat hidup secara layak. Pemerintah, dapat menciptakan iklim yang kondusif guna mendukung upaya tersebut. Misalnya, pendidikan (formal maupun non formal) dan kesehatan menjadi aspek terpenting serta diprioritaskan. 
2) Meningkatkan pemerataan. Dalam rangka meningkatkan produktivitas masyarakat, maka setiap penduduk harus memiliki kesempatan dan akses yang sama terhadap sumber daya ekonomi dan sosial yang tersedia. Kebijakan pembangunan yang berwawasan pembangunan manusia, selalu berorientasi pada pemerataan dan cenderung tidak diskriminatif. Setiap penduduk, laki-laki ataupun perempuan, dari kota maupun desa, dan pokoknya siapapun diupayakan agar memperoleh kesempatan dan akses yang sama secara proporsional. Bebagai kemudahan (akses) harus tercipta, baik ekonomi maupun sosial, kepada setiap penduduk. Hambatan-hambatan yang memperkecil kesempatan untuk memperoleh akses harus dihapus, sehingga dapat mengambil manfaat dari kesempatan yang ada dan berpartisipasi dalam kegiatan yang meningkatkan kualitas hidup.

3) Meningkatkan kesinambungan. Pemberian akses terhadap sumberdaya ekonomi dan sosial, harus dipastikan tidak hanya untuk generasi-generasi sekarang, tetapi harus dipikirkan juga untuk generasi-generasi mendatang. Semua sumberdaya (fisik, manusia, dan lingkungan) jangan sampai habis atau rusak, namun harus selalu diperbaharui. Kebijakan pembangunan ke depan, memberikan prioritas pada upaya untuk menerapkan konsep pembangunan berwawasan lingkungan secara tepat dan meluas.

4) Meningkatkan pemberdayaan. Penduduk harus dilibatkan atau terlibat dalam pengambilan keputusan dan proses yang membentuk kehidupan mereka. Penduduk harus diberikan kesempatan dalam mengambil manfaat dari proses pembangunan (penerima manfaat). Oleh karena itu, pembangunan harus "oleh" penduduk dan bukannya hanya "untuk" penduduk. Dalam hal ini, kebijakan pembangunan manusia harus selalu diarahkan pada upaya untuk mendorong dan menemukenali permasalahannya sendiri, mengatasi sendiri dan untuk mereka sendiri dalam batas kemampuannya. Kebijakan pembangunan manusia pada masa akan datang, harus diarahkan pada proses pemberdayaan masyarakat. 
Kedua, dalam rangka mempromosikan dan melaksanakan pembangunan manusia secara nyata di seluruh wilayah Indonesia, Ditjen Bina Pembangunan Daerah bermitra dengan BPS, menetapkan kebijakan sebagai berikut :

1) Memberikan petunjuk atau advokasi pembangunan manusia, dalam menyebarluaskan pemahaman tentang hakekat pembangunan yang berpusat pada manusia.

2) Melakukan penyederhanaan pembangunan manusia yang dimunculkan melalui Indeks Pembangunan Manusia (IPM) sebagai ukuran atau indikator pembangunan, baik untuk keperluan evaluasi, advokasi, maupun perencanaan dan perumusan kebijakan pembangunan daerah.

3) Menyiapkan metode penyusunan laporan kondisi pembangunan manusia (LPM), dan analisa situasi pembangunan manusia (ASPM) untuk digunakan daerah, sebagai dasar penyusunan kebijakan pembangunan manusia sesuai dengan permasalahan di berbagai daerah melalui pendekatan regional atau wilayah.

4) Menyiapkan penyusunan IPM tingkat kabupaten/kota, sebagai instrumen evaluasi kinerja pembangunan kabupaten/kota dalam skala nasional. (Susiyanto, 2016)

\section{INDEKS PEMBANGUNAN MANUSIA}

Pembangunan manusia adalah proses perluasan pilihan masyarakat, pilihan manusia sangat banyak jumlahnya dan berubah setiap saat. Namun pada semua tingkatan pembangunan, terdapat tiga pilihan paling mendasar yaitu umur panjang dan hidup sehat, memperoleh pendidikan dan memiliki kemampuan untuk mengakses berbagai sumber kebutuhan agar dapat secara hidup layak. Apabila ketiga hal mendasar tersebut terpenuhi maka pilihan lainnya juga tidak dapat dijangkau dengan baik.

Indeks Pembangunan Manusia (IPM) atau Human Development Index (HDI) merupakan ukuran dari harapan untuk hidup, kemampuan membaca dan menulis, pendidikan dan standar atau kualitas hidup untuk semua negara di dunia. IPM berguna untuk proses klasifikasi apakah sebuah negara merupakan negara maju, negara berkembang atau 
negara terbelakang, atau mengukur pengaruh kebijaksanaan ekonomi terhadap kualitas hidup manusia.

IPM dikembangkan oleh Amartya Sen pemenang nobel India dan Mahbub ul Haq ekonom Pakistan, serta dibantu oleh Gustav Ranis (Universitas Yale) dan Lord Meghnad Desai (London School of Economics) tahun 1990. Sejak itu, IPM gunakan oleh PBB dalam laporan IPM tahunannya. IPM difokuskan untuk hal-hal yang lebih peka dan berguna daripada hanya sekadar melihat pendapatan perkapita yang selama ini digunakan. IPM juga digunakan para peneliti yang serius sebagai media untuk mengetahui hal-hal yang lebih terinci dalam membuat laporan pembangunan manusianya.

\section{Dimensi Dasar IPM}

Dalam menghitung Indeks Pembangunan Manusia (IPM) digunakan tiga (3) dimensi sebagai dasar pengukurannya :

a) Umur panjang dan hidup sehat pengukurannya dengan angka harapan hidup saat kelahiran

Umur Harapan Hidup (UHH) merupakan rerata perkiraan banyaknya tahun yang dapat dijalan oleh seseorang selama hidup sejak kelahirannya. Angka harapan hidup dihitung melalui pendekatan tak langsung (indirect estimation). Jenis data yang digunakan adalah Anak Lahir Hidup (ALH) dan Anak Masih Hidup (AMH). Program Mortpack digunakan untuk menghitung angka harapan hidup dalam menginput data ALH dan AMH. Pemilihan Metode Trussel dengan model West, sesuai dengan histori kependudukan dan kondisi Indonesia dan negara-negara Asia Tenggara umumnya (Preston, 2004). Sesuai standar UNDP, Indeks harapan hidup dihitung dengan angka tertinggi sebagai batas maksimum dipakai 85 tahun dan terendah adalah 20 tahun.

b) Angka Harapan Sekolah dan Angka Rata-Rata Lama Sekolah (Dimensi Pengetahuan). Dimensi pengetahuan sebagai pembentuk IPM diukur melalui indeks tingkat pendidikan. Indikator yang digunakan adalah Rata - Rata Lama Sekolah (mean years of schooling) dan Harapan Lama Sekolah (expected years of schooling), dua indikator ini 
diberi bobot yang sama, kemudian digabung dan digunakan sebagai komponen pembentuk IPM.

Harapan lama sekolah adalah lamanya bersekolah (dalam tahun) yang diharapkan mampu dilalui oleh anak atau penduduk berusia 7 tahun ke atas pada yang akan mendatang. Harapan lama sekolah digunakan untuk mengetahui kondisi pembangunan sistem pendidikan pada berbagai jenjang dalam bentuk lamanya pendidikan (tahun) yang diharapkan dapat dicapai oleh setiap anak (penduduk). Harapan lama sekolah menggunakan batasan yang disepakati UNDP, batas maksimum adalah 18 tahun, sedangkan batas minimumnya 0 (nol) tahun.

Rata-rata lama sekolah menggambarkan jumlah tahun yang digunakan oleh penduduk usia 25 tahun ke atas selama atau dalam menjalani pendidikan formal. Rata-rata lama sekolah dihitung menggunakan batasan yang disepakati oleh UNDP. Rata-rata lama sekolah memiliki batas maksimumnya 15 tahun dan batas minimum sebesar 0 tahun.

c) Standar kehidupan layak yang diturunkan dari Produk Domestik Bruto/PDB (Kemampuan Belanja Per kapita).

Dimensi lain IPM adalah standar hidup layak. Secara luas, standar hidup layak menunjukkan tingkat kesejahteraan yang dapat dinikmati oleh penduduk sebagai dampak semakin membaiknya perekonomian. UNDP menggunakan Produk Nasional Bruto (PNB) per kapita yang disesuaikan untuk mengukur standar hidup layak, sedangkan BPS menggunakan rata-rata pengeluaran per kapita riil yang disesuaikan dengan paritas daya beli (purcashing power parity) dengan basis Formula Rao. 


$$
P P P_{j}=\prod_{i=1}^{m}\left(\frac{p_{i j}}{p_{i k}}\right)^{1 / m}
$$

Keterangan :

PPPj:Paritas Daya Beli di wilayah j

Pij:Harga komoditas i di kabupaten/kota j

Pik:Harga komodita i di provinsi $k$

m:Jumlah komoditas

Pengukuran paritas daya beli berdasarkan 96 komoditas bahan atau kebutuhan pokok.

Batas maksimum pengeluaran perkapita sebesar $\mathrm{Rp} 26.572 .352$ sedangkan batas minimumnya sebesar Rp. 1.007.436.

\section{Manfaat IPM}

Menurut Badan Pusat Statisitik (BPS) pengukuran Indeks Pembangunan Manusia (IPM) bermanfaat untuk : (a) Mengukur keberhasilan pembangunan kualitas hidup masyarakat atau penduduk, (b) Menentukan peringkat pembangunan pada suatu wilayah atau negara, dan (c) Bagi Indonesia, digunakan sebagai ukuran kinerja Pemerintahdan salah satu alokator penentuan besaran Dana Alokasi Umum (DAU).

\section{Penyusunan IPM}

Sebelum perhitungan angka IPM, masing-masing komponen pembentuk harus dihitung indeksnya, dengan menggunakan formulasi sebagai berikut :

$$
\begin{aligned}
& \text { Indeks }_{A H H}=\frac{A H H-A H H_{\min }}{A H H_{\max }-A H H_{\min }} \\
& \text { Indeks }_{H L S}=\frac{H L S-H L S_{\min }}{H L S_{\max }-H L S_{\min }} \\
& \text { Indeks }_{R L S}=\frac{R L S-R L S_{\min }}{R L S_{\max }-R L S_{\min }} \\
& \text { Indeks }_{\text {Pengetahun }}=\frac{\text { Indeks }_{H L S}+\text { Indeks }_{R L S}}{2} \\
& \text { Indeks }_{\text {Pengeluaran }}=\frac{\ln (\text { pengeluaran })-\ln \left(\text { pengeluara }_{\text {min }}\right)}{\ln \left(\text { pengeluara }_{\max }\right)-\ln \left(\text { pengeluaran }_{\text {min }}\right)}
\end{aligned}
$$


Penghitungan indeks komponen IPM menggunakan batas maksimum dan minimum sebagai berikut :

\begin{tabular}{|l|c|c|c|}
\hline \multicolumn{1}{|c|}{ Komponen } & Satuan & Minimun & Maksimum \\
\hline Angka Harapan Hidup (AHH) & Tahun & 20 & 85 \\
\hline Harapan Lama Sekolah (HLS) & Tahun & 0 & 18 \\
\hline Rata-Rata Lama Sekolah (RLS) & Tahun & 0 & 15 \\
\hline Pengeluaran per Kapita & Rupiah & 1.007 .436 & 26.572 .325 \\
\hline
\end{tabular}

Sehingga nilai IPM dapat dihitung sebagai :

$I P M=\sqrt[3]{\text { Indeks }_{\text {Kesehatan }} x \text { Indeks }_{\text {Pendidikan }} x \text { Indeks }_{\text {Pengeluaran }}}$

Capaian pembangunan manusia dalam suatu wilayah pada waktu tertentu dikelompokkan ke dalam empat kelompok. Pengelompokkan dimaksudkan untuk mengkluster wilayah tertentu dalam implementasi kebijakan pembangunan manusia.

\begin{tabular}{|c|c|}
\hline Angka IPM & Status \\
\hline IPM $\geq 80$ & Sangat Tinggi \\
\hline $70 \leq$ IPM $<80$ & Tinggi \\
\hline $60 \leq$ IPM $<70$ & Sedang \\
\hline IPM $<60$ & Rendah \\
\hline
\end{tabular}

\section{KEMISKINAN DAN DISTRIBUSI PENDAPATAN}

Menurut Michael Sherraden (2006), Kemiskinan terbagi dalam dua kategori yang saling bertentangan dan teori yang tidak memihak (middle ground). Pertama, teori yang berorientasi pada perilaku individu (behavioral) atau teori struktur sosial masyarakat. Kedua, teori mengenai budaya miskin. Teori yang berorientasi perilaku individu merupakan teori tentang pilihan, harapan, sikap, motivasi dan modal manusia (human capital). Teori perilaku individu meyakini bahwa sikap individu yang tidak produktif menyebabkan lahirnya kemiskinan. Sedangkan, budaya miskin merujuk pada faktor internal indvidu yang menganut budaya yang menghambat penerimaan terhadap pembaharuan, dan faktor eksternalnya berkaitan dengan birokrasi atau aturan yang menghambat masyarakat memanfaatkan sumberdaya yang tersedia. 
Tingkat pertumbuhan ekonomi tinggi bagi sebagian besar penduduk dunia tidak memberikan jalan keluar bagi kemiskinan dan ketimpangan distribusi pendapatan, ketika tingkat pertumbuhan ekonomi yang tinggi diikuti dengan meningkatnya tingkat pengangguran di pedesaaan maupun perkotaan. Distribusi pendapatan antara kelompok kaya dengan miskin semakin melebar. Pertumbuhan ekonomi yang tinggi ternyata tidak mampu menghilangkan atau bahkan mengurangi kondisi kemiskinan absolut terutama di negara sedang berkembang.

Menurut Adelman dan Morris (1973) dalam Arsyad (2004), mengemukakan 8 (delapan) faktor penyebab tidak meratanya distribusi pendapatan di negara sedang berkembang, yaitu:

a) Pertambahan jumlah penduduk yang tinggi menyebakan menurunnya pendapatan perkapita masyarakat;

b) Kenaikan-harga komoditas tidak diikuti dengan pertambahan kapasitas produksi secara proporsional;

c) Ketimpangan pembangunan antar daerah;

d) Proporsi investasi padat modal (capital intensive) dalam suatu negara yang lebih besar dari investasi berbasis padat karya menyebabkan meningktnya pengangguran;

e) Rendahnya mobilitas sosial;

f) Kebijakan sektor industri, substitusi impor yang mengakibatkan kenaikan harga-harga barang hasil industri cenderung melindungi usaha golongan kapitalis;

g) Memburuknya nilai tukar (term of trade) bagi negara sedang berkembang dalam perdagangan dengan negara maju, sebagai akibat ketidakelastisan permintaan negara maju terhadap barang ekspor negara sedang berkembang;

h) Tidak berkembangnya industri kecil atau industri kerajinan rakyat seperti pertukangan, industri rumah tangga, dan lain-lain.

Distribusi pendapatan secara faktual dapat berwujud pemerataan maupun ketimpangan, yang digambarkan dari tingkat pembagian pendapatan yang dihasilkan dari berbagai kegiatan atau aktivitas ekonomi. Distribusi dari suatu proses produksi terjadi setelah diperoleh pendapatan dari suatu kegiatan usaha. Masalah pemerataan pendapatan 
sejak lama menjadi perdebatan di kalangan masyarakat dan akademisi dari sisi pendekatan pengukurannya. Pendekatan pengukuran yang sering digunakan mengukur ketidakmerataan distribusi pendapatan melalui Gini coefficient menggunakan Kurva Lorentz. Untuk mengukur tingkat kemiskinan digunakan metode headcount measure dan poverty gap. Ukuran yang dipakai dalam menentukan ketidakmerataan baik di tingkat wilayah maupun rumah tangga adalah gini coefficient dan tingkat kemiskinan.

\section{PENDAPATAN PERKAPITA}

Pendapatan merupakan jumlah uang tertentu yang diterima individu atau rumah tangga dalam jangka waktu satu tahun. Pendapatan berasal dari upah tenaga kerja, pendapatan dari kekayaan seperti sewa, bunga dan deviden serta pembayaran atau penerimaan tunjangan sosial atau asuransi pengangguran (Samuelson dan Nordhaus, 1993). Winardi (1991), mendefinisikan pendapatan sebagai barang dan jasa yang dapat dikonsumsi selama periode tertentu.

PDRB (Produk Domestik Regional Bruto) merupakan jumlah nilai tambah yang dihasilkan oleh seluruh unit usaha dalam suatu wilayah atau jumlah seluruh nilai barang dan jasa akhir yang dihasilkan oleh seluruh unit ekonomi didalam suatu wilayah. Jika nilai PDRB dibagi jumlah penduduk di wilayah tersebut diperoleh pendapatan perkapita. Penghitungan PDRB dilakukan atas dasar harga berlaku dan harga konstan dengan tujuan berbeda. Penghitungan PDRB ADHB digunakan untuk melihat pergeseran dan struktur ekonomi dari tahun ke tahun, sedang penghitungan PDRB ADHK digunakan untuk mengetahui pertumbuhan ekonomi dari tahun ke tahun.

Pertumbuhan pendapatan perkapita yang positif dari tahun ke tahun menjadi indikator laju pertumbuhan ekonomi, dimana peningkatan pendapatan akan meningkatkan taraf kesejahteraan dan kemampuan masyarakat untuk memenuhi kebutuhannya. Dalam rangka pemenuhan kebutuhan tersebut masyarakat akan membelanjakan pendapatan yang diterima di sektor-sektor ekonomi yang berdampak pada berputarnya roda perekonomian di daerah. 


\section{HIPOTESA}

$\mathrm{H}_{1}$ :Diduga Angka Harapan Hidup, Harapan Lama Sekolah, Rata-Rata Lama Sekolah dan Pengeluaran Per Kapita mempunyai korelasi yang sangat kuat dan signifikan dengan IPM;

$\mathrm{H}_{2}$ :Diduga IPM mempunyai pengaruh yang signifikan dan negatif terhadap tingkat kemiskinan;

$\mathrm{H}_{3}$ :Diduga IPM mempunya pengaruh yang signifikan dan positip terhadap pendapatan per kapita:

\section{METODE PENELITIAN}

\section{DESAIN PENELITIAN}

Pendekatan yang digunakan dalam penelitian ini adalah analisis kuantitatif. Analisis kuantitatif menekankan kajiannya pada data numerik atau angka yang diperoleh melalui pendekatan statistik pada penelitian inferensial atau dalam rangka pengujian hipotesis sehingga diperoleh signifikansi hubungan antara variabel-variabel yang diteliti. Sugiyono (2012), mengemukakan bahwa penelitian kuantitatif merupakan suatu metode penelitian yang berakar dari filsafat positivism, sehingga digunakan untuk meneliti populasi atau sampel tertentu, pengumpulan data menggunakan instrumen penelitian, analisis data bersifat kuantitatif, dengan tujuan pengujian hipotesa. Penelitian ini secara khusus mengukur pengaruh variabel bebas dalam hal ini pembangunan manusia yang dicermati melalui angka dari Indeks Pembangunan Manusia, terhadap variabel tidak bebas meliputi tingkat kemiskinan dan pendapatan perkapita.

\section{JENIS DAN SUMBER DATA}

Jenis data yang digunakan dalam kajian ini adalah data kuantitatif. Berdasarkan sumbernya data penelitian merupakan data sekunder. Sumber data sekunder berasal dari catatan atau dokumentasi perusahaan, dokumentasi institusi resmi pemerintah, analisis industri oleh media, situs Web, internet dan lain-lainnya (Uma Sekaran, 2011). Data 
sekunder yang digunakan dalam kajian ini terdiri dari : Data Indeks Pembangunan Manusia (IPM), Tingkat Kemiskinan dan Pendapatan Perkapita Provinsi Papua periode 2010 - 2018. Data - data tersebut diperoleh dari hasil publikasi BPS Provinsi Papua dan BPS Indonesia.

\section{TEHNIK PENGUMPULAN DATA}

\section{Studi Dokumen}

Studi dokumen merupakan metode pengumpulan data yang tidak ditujukan langsung kepada subjek penelitiannya. Studi dokumen merupakan metode pengumpulan data dari berbagai macam dan jenis dokumen yang berguna untuk bahan analisis, yang telah disajikan oleh berbagai pihak.

\section{Internet}

Penulis melakukan penelusuran melalui internet terhadap berbagai informasi yang relevan dengan permasalahan yang akan diteliti.

\section{TEHNIK ANALISIS DATA}

Dalam rangka menjawab pertanyaan penelitian yang telah ditetapkan dalam rumusan masalah maka penulis menggunakan beberapa analisis sebagai berikut :

\section{Analisis Korelasi}

Analisis Korelasi mengukur kekuatan hubungan antara dua variabel (kadang lebih dari dua variabel) dengan skala-skala tertentu. Korelasi Pearson, data harus berskala interval atau rasio; korelasi Spearman dan Kendal menggunakan data skala ordinal; Chi Square menggunakan data nominal. Korelasi mempunyai kemungkinan pengujian hipotesis dua arah (two tailed). Korelasi searah jika nilai koefesien korelasinya positif; jika nilai koefesien korelasi negatif, maka korelasi tidak searah. Adapun nilai korelasi dalam interval : (Sugiyono, 2009)

$$
-1 \leq \rho \leq 1
$$

Mengukur koefisien korelasi dengan product moment :

$$
\mathrm{r}=\frac{\mathrm{n} \sum \mathrm{X} Y-\sum \mathrm{X} \sum \mathrm{Y}}{\sqrt{\left[\mathrm{n}\left(\sum \mathrm{X}^{2}\right)-\left(\sum \mathrm{X}\right)^{2}\right]\left[\mathrm{n}\left(\sum \mathrm{Y}^{2}\right)-\left(\sum \mathrm{Y}\right)^{2}\right]}}
$$


Dengan Ketentuan :

(1) Jika nilai $r>0$, terjadi hubungan linier positif (positive correlation), yaitu makin besar nilai variabel $X$ makin besar pula nilai variabel $Y$, atau makin kecil nilai variabel $X$ makin kecil pula nilai variabel $Y$.

(2) Jika nilai $r<0$, terjadi hubungan yang linier negatif (negative correlation), yaitu makin besar nilai variabel $X$ makin kecil nilai variabel $Y$, atau makin kecil nilai variabel $X$ maka makin besar pula nilai variabel $Y$.

(3) Jika nilai $r=0$, tidak ada hubungan sama sekali antara variabel $X$ dan variabel $Y$.

(4) Jika nilai $r=1$ atau $r=-1$, terjadi hubungan linier sempurna, berupa garis lurus, sedangkan untuk $r$ yang makin mengarah ke arah angka 0 (nol) maka garis makin tidak lurus.

\section{Analisis Regresi}

Analisis regresi merupakan studi ketergantungan satu atau lebih variabel bebas terhadap variabel tidak bebas, dengan maksud untuk meramalkan nilai variabel tidak bebas. Banyak metode untuk menaksir koefisien regresi pada sebuah model, salah satunya yang paling banyak digunakan adalah metode OLS (ordinary least square). (Sugiyono, 2011)

$$
\begin{gathered}
\mathrm{Y}=\mathrm{a}+\mathrm{bX} \\
b=\frac{\sum x y-\frac{\left(\sum x\right)\left(\sum y\right)}{n}}{\sum x^{2}-\frac{\left(\sum x\right)^{2}}{n}} \\
a=\bar{y}-b_{1} \bar{x}
\end{gathered}
$$

Dimana :

$Y \quad$ : merupakan variabel terikat, yang dalam penelitian ini terdiri dari tingkat kemiskinan dan Pendapatan perkapita.

$X \quad$ : merupakan variabel bebas yang dalam penelitian adalah Indeks Pembangunan Manusia (IPM).

a : Konstanta, nilai $Y$ ketika nilai $X=0$

b : Koefisien Regresi

Rumus yang digunakan untuk menguji koefisien regresi dan ketentuannya adalah:

$$
t \text { - stat }=\frac{b-\beta}{S_{b}}
$$

Kriteria Pengujian Hipotesa :

- Terima $H_{0} j i k a-t_{0.025(n-k)}<t$-stat $<+t_{0.025(n-k)}$ atau terima $H_{0} j i k a$-value $>0,05$

- $\quad$ Tolak $H_{0}$ jika $-t_{0.025(n-k)}>t$-stat $>+t_{0.025(n-k)}$ atau tolak $H_{0}$ jika $p$-value $<0,05$ 


\section{HASIL PENELITIAN DAN PEMBAHASAN}

\section{INDEKS PEMBANGUNAN MANUSIA}

IPM Provinsi Papua selama kurun waktu penelitian mengalami peningkatan yang cukup tinggi hal ini terlihat dari capaian angka IPM tahun 2010 sebesar 55,45 (kategori rendah) meningkat hingga pada tahun 2018 mencapai 60,06 (kategori sedang). Jika berdasarkan kabupaten/kota terlihat bahwa pada tahun 2018 terdapat 12 kabupaten dan kota yang memiliki angka IPM diatas provinsi, sedangkan selebihnya berada dibawah angka provinsi.

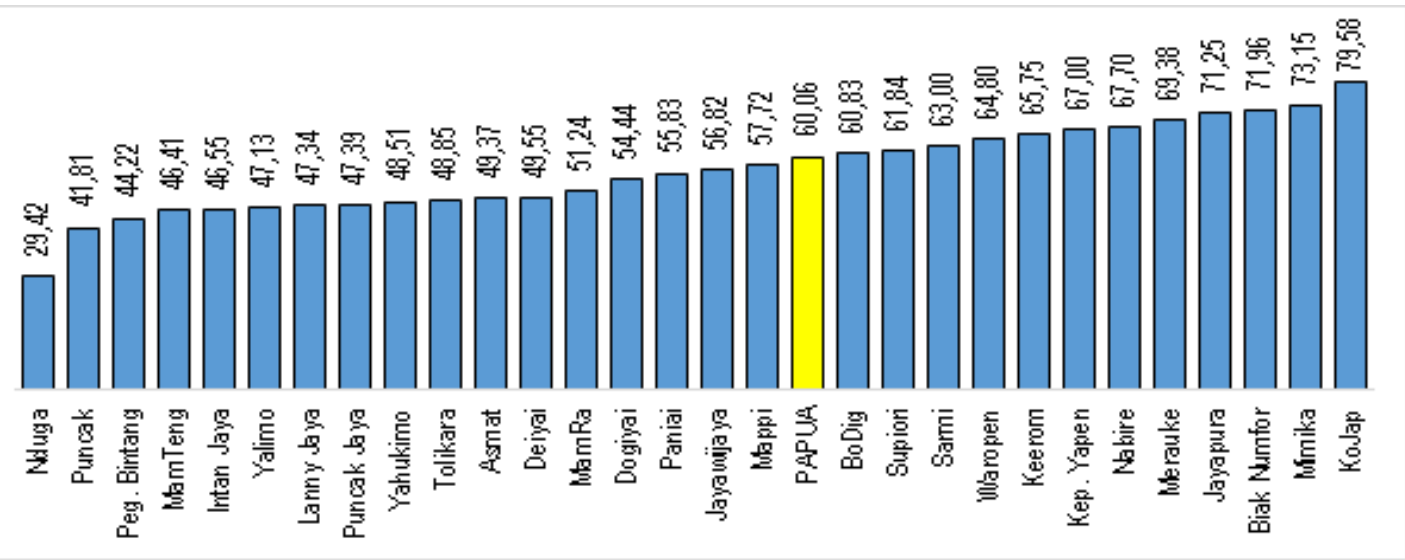

\section{Gambar 1. IPM Kabupaten/ Kota di Provinsi Papua Tahun 2018 Sumber : BPS Papua, 2018}

Pada tahun 2018 terdapat 8 kabupaten dengan kategori sedang atau memiliki angka berkisar antara ( 60,01 hingga 70,00) yaitu : Boven Digul, Supiori, Sarmi, Waropen, Kepulauan Yapen, Nabire dan Merauke. Di tahun yang sama terdapat 4 kabupaten/kota yang memiliki angka IPM diatas 70 atau masuk dalam kategori tinggi antara lain Kabupaten Jayapura, Biak Numfor, Mimika dan Kota Jayapura. Publikasi BPS menunjukkan bahwa pada tahun 2018 angka IPM kabupaten/kota di Papua berkisar antara 29,42 (terendah) di Kabupaten Nduga dan 79,58 (tertinggi) di Kota Jayapura. 


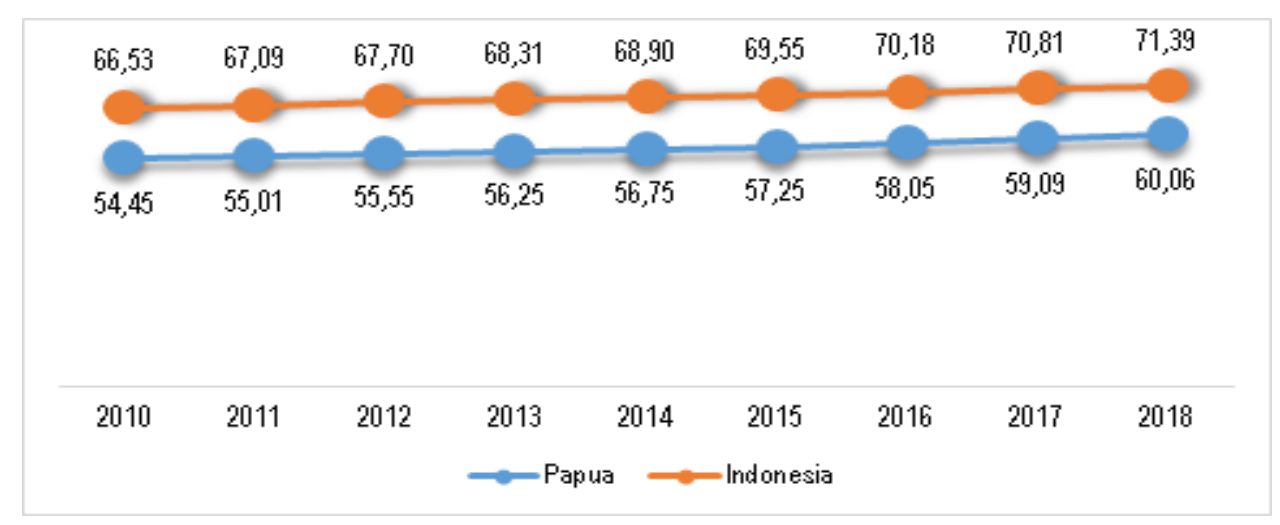

Gambar 2. IPM Indonesia dan Papua, Tahun 2010 - 2018

Sumber : BPS Papua \& BPS Pusat, 2018

Jika dibandingkan dengan angka IPM nasional atau Indonesia memang terlihat bahwa angka IPM nasional lebih tinggi dibanding Papua. Pada tahun 2010 IPM Indonesia berada pada angka 66,53 sedangkan Papua di angka 54,45 sehingga ada gap/selisih sebesar 12,08 point. Angka IPM nasional maupun Papua sama-sama mengalami peningkatan, hingga tahun 2018 angka IPM Indonesia mencapai 71,39 sedangkan Papua sebesar 60,06 dimana terdapat selisih atau gap antara keduanya sebesar 11,33 point. Walaupun terdapat selisih yang cukup besar namun pertumbuhan angka IPM yang dicapai Provinsi Papua lebih besar dibanding Indonesia. Dalam kurun waktu penelitian angka IPM Papua mengalami pertumbuhan sebesar 1,23 persen sedangkan Indonesia mengalami pertumbuhan sebesar 0,89 persen.

\section{Angka Harapan Hidup (AHH)}

Angka Harapan Hidup (AHH), merupakan perkiraan usia hidup individu dihitung sejak dilahirkan (tahun). BPS mendefinisikan rata-rata tahun hidup yang akan dijalani oleh seseorang yang telah mencapai umur $\mathrm{x}$, pada suatu tahun tertentu dalam kondisi mortalitas yang berlaku di lingkungan masyarakatnya. 


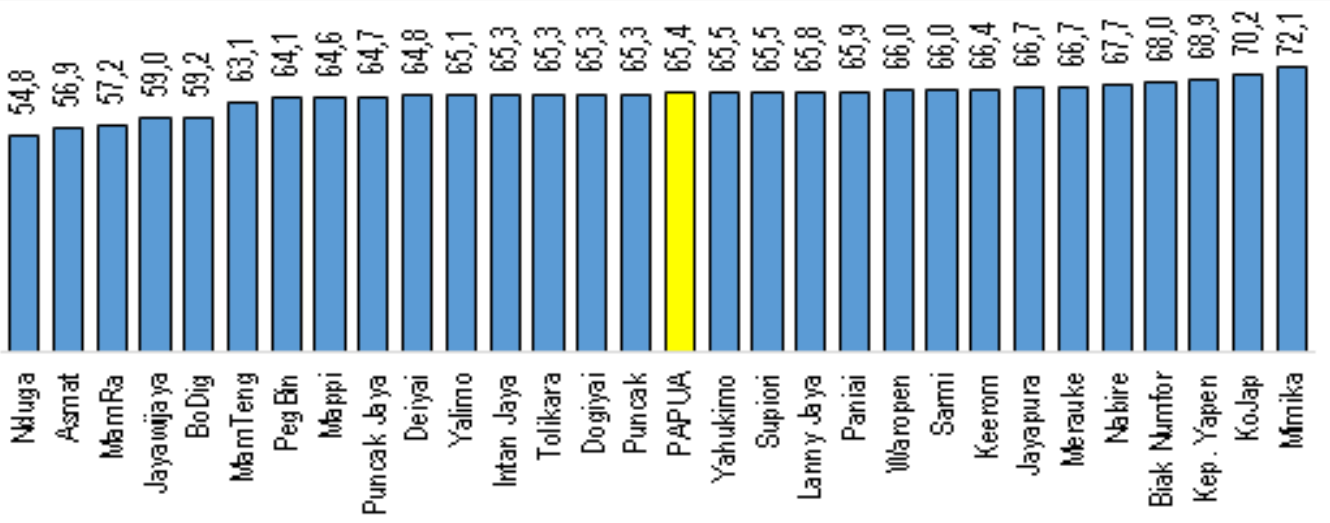

Gambar 3. AHH Kabupaten / Kota di Provinsi Papua, Tahun 2018 (Tahun) Sumber : BPS Papua, 2018

Pada tahun $2010 \mathrm{AHH}$ Provinsi Papua sebesar 64,3 tahun, pada periode selanjutnya AHH mengalami peningkatan hingga mencapai angka 65,4 tahun pada tahun 2018 . Kabupaten Nduga memiliki AHH terendah pada tahun 2010 berada pada angka 52,7 tahun hingga tahun 2018 mencapai angka atau sebesar 54,8 tahun. Sedangkan Kabupaten Mimika memiliki angka AHH tertinggi di Papua tahun 2018 sebesar 72,1 tahun dimana pada tahun 2010 sebesar 71,7 tahun.

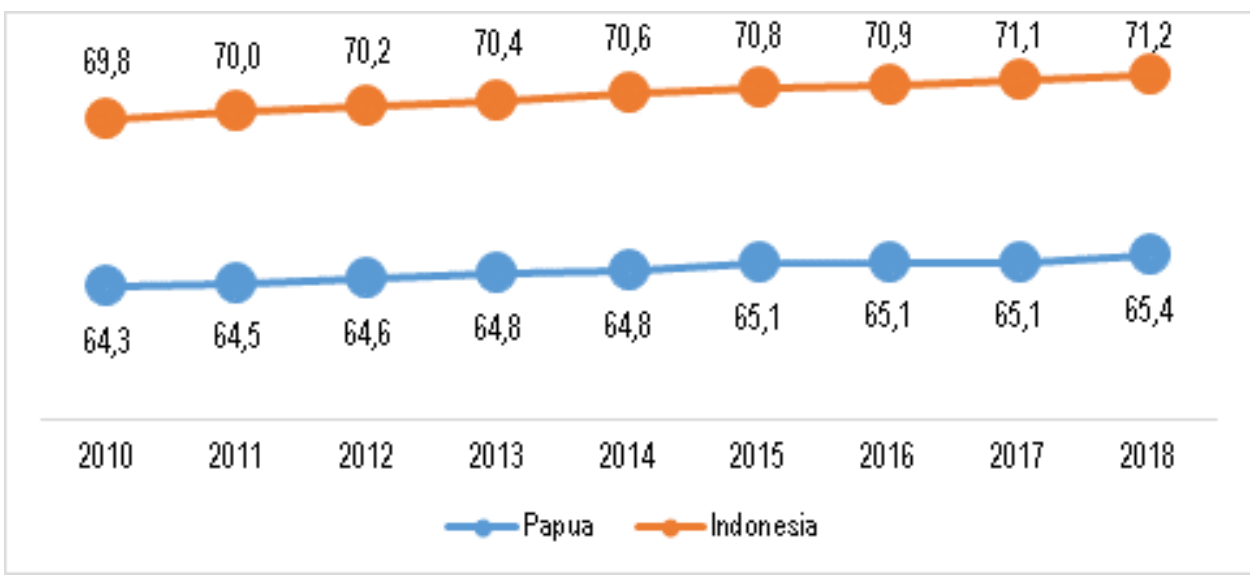

Gambar 4. AHH Indonesia dan Papua, Tahun 2010 - 2018 (Tahun)

Sumber : BPS Papua \& BPS Pusat, 2018

Selama periode penelitian $\mathrm{AHH}$ Indonesia maupun Papua sama-sama mengalami peningkatan, di tahun $2010 \mathrm{AHH}$ Indonesia berada pada angka 69,8 tahun dan Papua mencatat angka 64,3 tahun. Hingga tahun 2018 Indonesia telah mencapai 71,2 tahun 
sedangkan Papua berada diangka 65,4 tahun. Dalam kurun waktu tersebut $\mathrm{AHH}$ Indonesia mengalami pertumbuhan sebesar 0,25 persen lebih tinggi dibanding Provinsi Papua dengan pertumbuhan $\mathrm{AHH}$ sebesar 0,20 persen.

\section{Harapan Lama Sekolah (HLS)}

Harapan lama sekolah adalah lamanya sekolah (tahun) yang diharapkan akan dirasakan oleh anak pada umur tertentu di masa mendatang. Harapan lama sekolah dihitung untuk penduduk atau anak berusia 7 tahun ke atas.

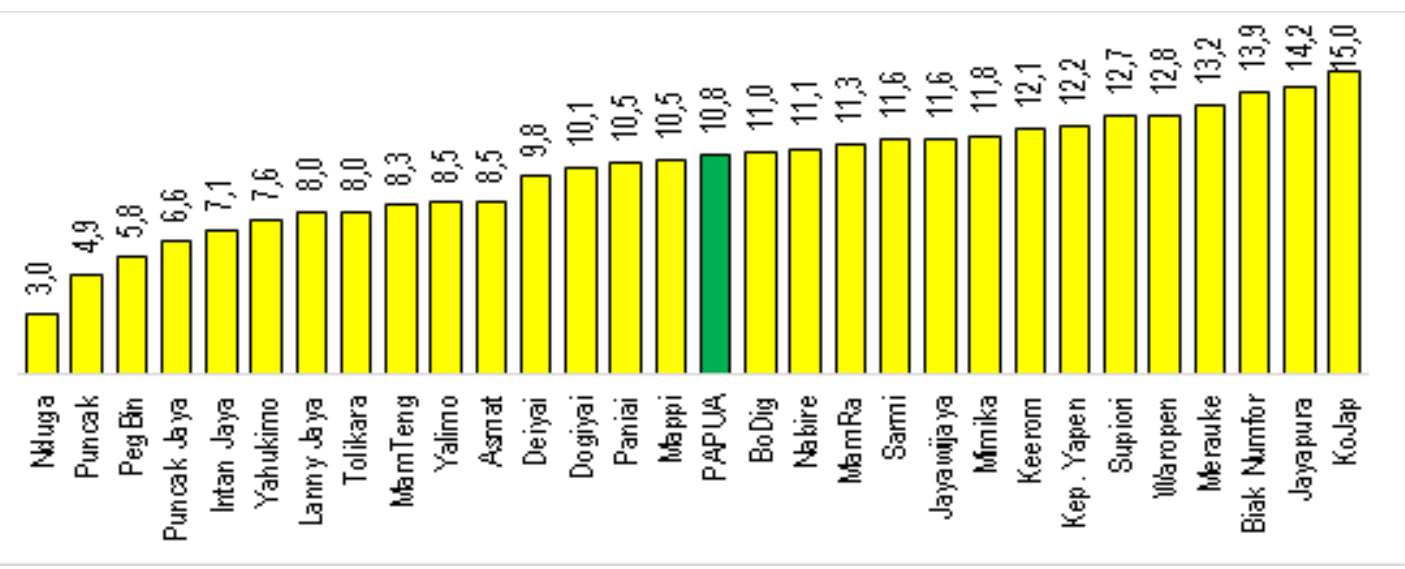

Gambar 5. HLS Kabupaten/Kota di Provinsi Papua, Tahun 2018 (Tahun) Sumber : BPS Papua, 2018

Pada tahun 2010 angka HLS Papua sebesar 8,6 tahun meningkat hingga mencapai 10,8 tahun pada periode 2018. Kabupaten Nduga memiliki angka HLS terendah dibanding lainnya yaitu sebesar 3 tahun sedangkan angka tertinggi di Kota Jayapura sebesar 15 tahun. Terlihat dalam gambar bahwa pada tahun 2018 hampir sebagian besar kabupaten di Wilayah adat Mepago dan Lapago memiliki angka HLS di bawah provinsi sedangkan kabupaten di wilayah Ha Anim, Mamta dan Saireri sebagian besar di atas angka HLS provinsi.

Jika mendeskripsikan angka yang dicapai Kabupaten Nduga pada tahun 2018, maka dapat kita nyatakan bahwa penduduk usia 7 tahun keatas hanya dapat mengeyam pendidikan sampai kelas 3 Sekolah Dasar. Sedangkan di Kota Jayapura dapat ditunjukkan bahwa penduduk usia 7 tahun di wilayah tersebut dapat mengenyam pendidikan atau 
diharapkan dapat bersekolah hingga 15 tahun atau dapat mengenyam pendidikan hingga perguruan tinggi minimal semester 6 atau menyelesaikan pendidikan Diploma III.

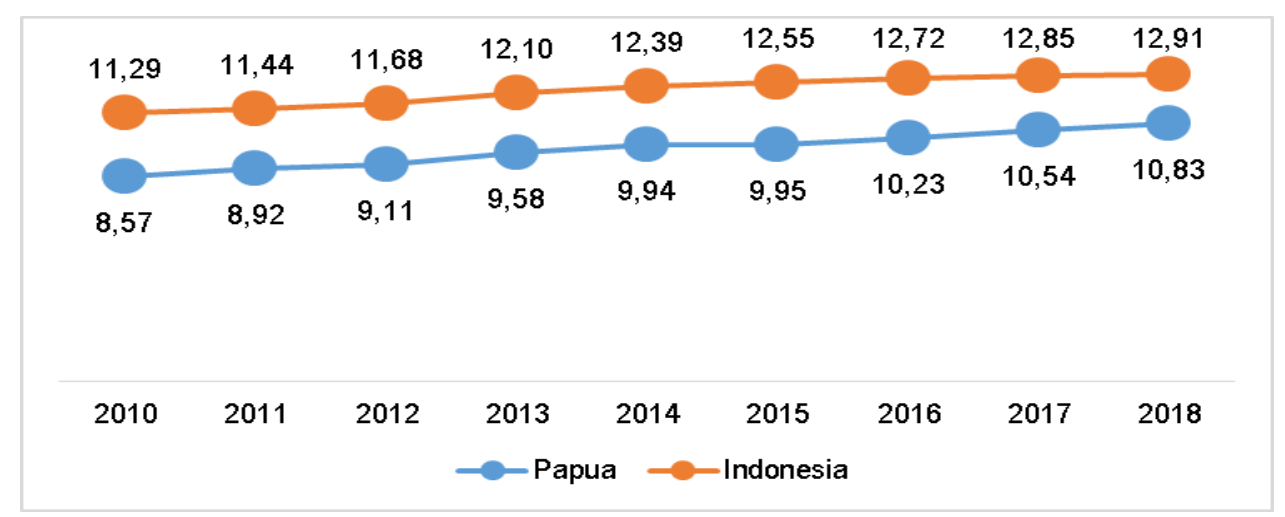

Gambar 6. HLS Indonesia dan Papua, Tahun 2010 - 2018 (Tahun)

Sumber : BPS Papua \& BPS Pusat, 2018

Selama periode penelitian perkembangan HLS Indonesia mengalami pertumbuhan rata-rata sebesar 1,69 persen, besaran pertumbuhan tersebut dibawah rata-rata pertumbuhan HLS Papua sebesar 2,98 persen. Namun bila dilihat dari besaran angka maka HLS Indonesia masih berada di atas Papua, pada tahun 2010 HLS Papua sebesar 8,57 tahun dan Indonesia sebesar 11,29 tahun hingga tahun 2018 Papua mencapai angka 10,83 tahun dan Indonesia sebesar 12,91 tahun, adapun selisih yang diperoleh rata-rata sebesar 2,47 point atau tahun.

\section{Rata-Rata Lama Sekolah (RLS)}

Rata-rata lama sekolah menunjukkan jumlah tahun yang digunakan oleh penduduk usia 25 tahun keatas dalam menjalani pendidikan formal. RLS dihitung menggunakan batasan yang disepakati UNDP, batas maksimumnya 15 tahun dan batas minimum sebesar 0 tahun. Merujuk batasan tersebut, maka seluruh kabupaten dan kota di Provinsi Papua belum ada yang mencapai batas maksimum yang ditetapkan.

Publikasi BPS tahun 2018 menunjukkan bahwa RLS tertinggi di Kota Jayapura sebesar 11 tahun, selanjutnya Kabupaten Biak Numfor 9,4 tahun, Jayapura dan Mimika masing-masing sebesar 9,2 tahun. Sedangkan Kabupaten Nduga memiliki angka RLS paling rendah di Papua sebesar 0,6 tahun, selain itu masih terdapat 15 kabupaten yang 
memiliki angka RLS di bawah provinsi dimana kabupaten tersebut berada di wilayah pegunungan tengah yang tersebar di wilayah adat Mepago dan Lapago.

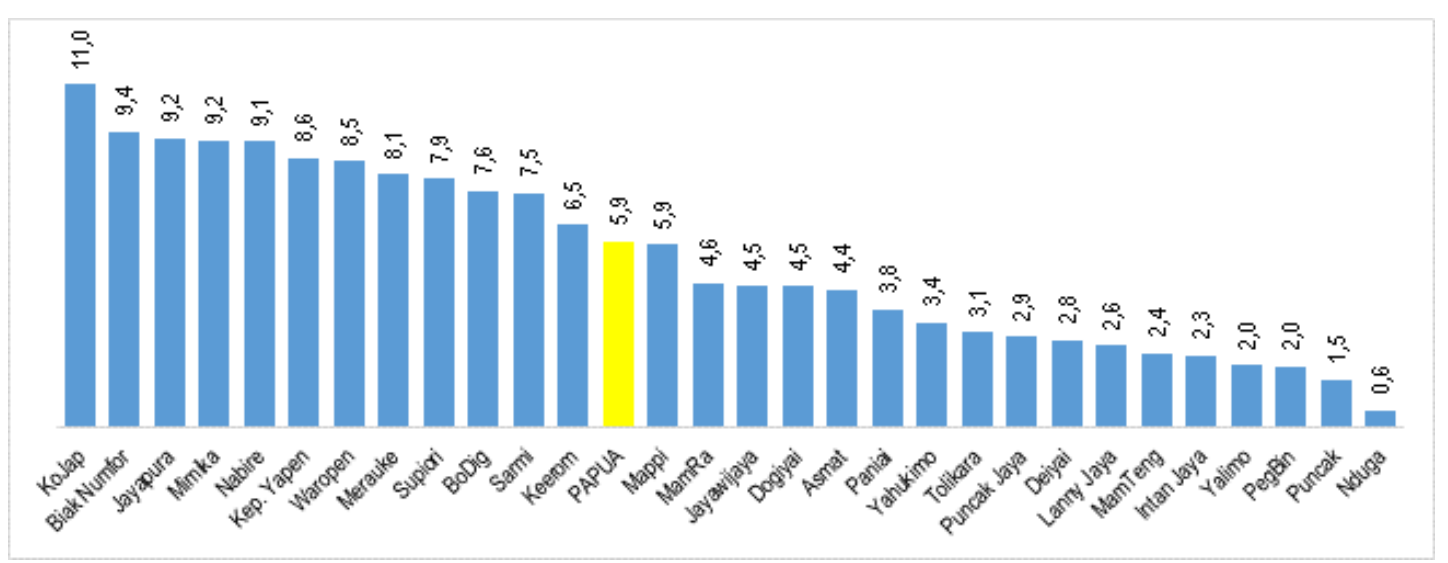

\section{Gambar 7. RLS Kabupaten/Kota di Papua, Tahun 2018 (Tahun)}

Sumber : BPS Papua, 2018

Pada tahun 2018, angka RLS Papua sebesar 5,9 tahun angka menunjukkan bahwa penduduk berusia 25 tahun keatas di Provinsi Papua rata-rata bersekolah atau mengenyam sampai pada jenjang kelas 5 atau kelas 6 sekolah dasar. Sesuatu yang agak miris karena hingga saat ini kesempatan atau peluang penduduk di Papua untuk berpartisipasi dalam dunia pendidikan masih sangat rendah. Akses untuk menikmati layanan publik pendidikan masih sangat terbatas.

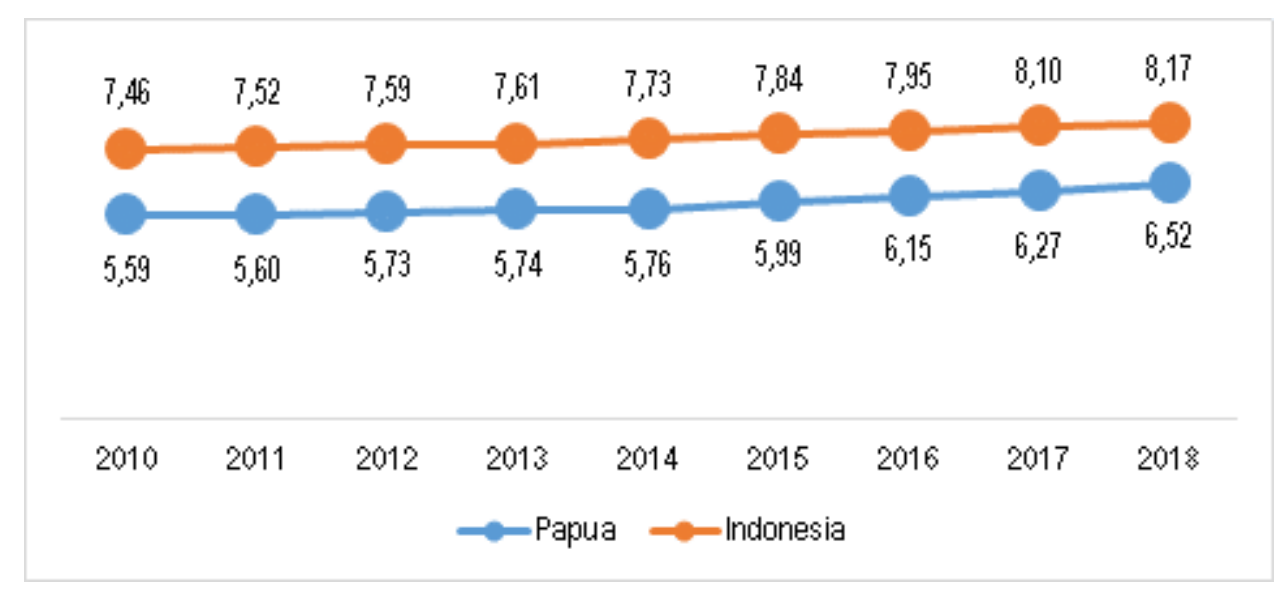

Gambar 8. RLS Indonesia dan Papua, Tahun 2010 - 2018 (Tahun)

Sumber : BPS Papua \& BPS Pusat, 2018

Dapat ditunjukkan bahwa angka RLS Papua dengan Nasional tidak terpaut jauh, misalnya pada tahun 2010 RLS Papua 5,59 tahun sedangkan nasional sebesar 7,46 tahun ada selisih sebesar 1,87 point atau tahun. Hingga tahun 2018, angka RLS Papua sebesar 
6,52 sedangkan nasional sebesar 8,17 tahun ada selisih sebesar 1,65 tahun. Kurun waktu tersebut RLS Papua mengalami pertumbuhan sebesar 1,95 persen, sedangkan Indonesia mengalami pertumbuhan sebesar 1,14 persen.

\section{Pengeluaran Perkapita (PP)}

Pengeluaran perkapita yang disesuaikan (dalam ribu rupiah) yaitu nilai pengeluaran perkapita dan paritas daya beli (purchasing power parity). Rata-rata pengeluaran perkapita dibuat konstan/riil dengan tahun dasar 2012=100. Penghitungan PPP menggunakan 96 komoditas dimana 66 komoditas merupakan makanan dan 30 komoditas merupakan komoditas nonmakanan. Batas maksimum pengeluaran per kapita adalah sebesar Rp 26.572.352 sementara batas minimumnya adalah $\mathrm{Rp} 1.007 .436$.

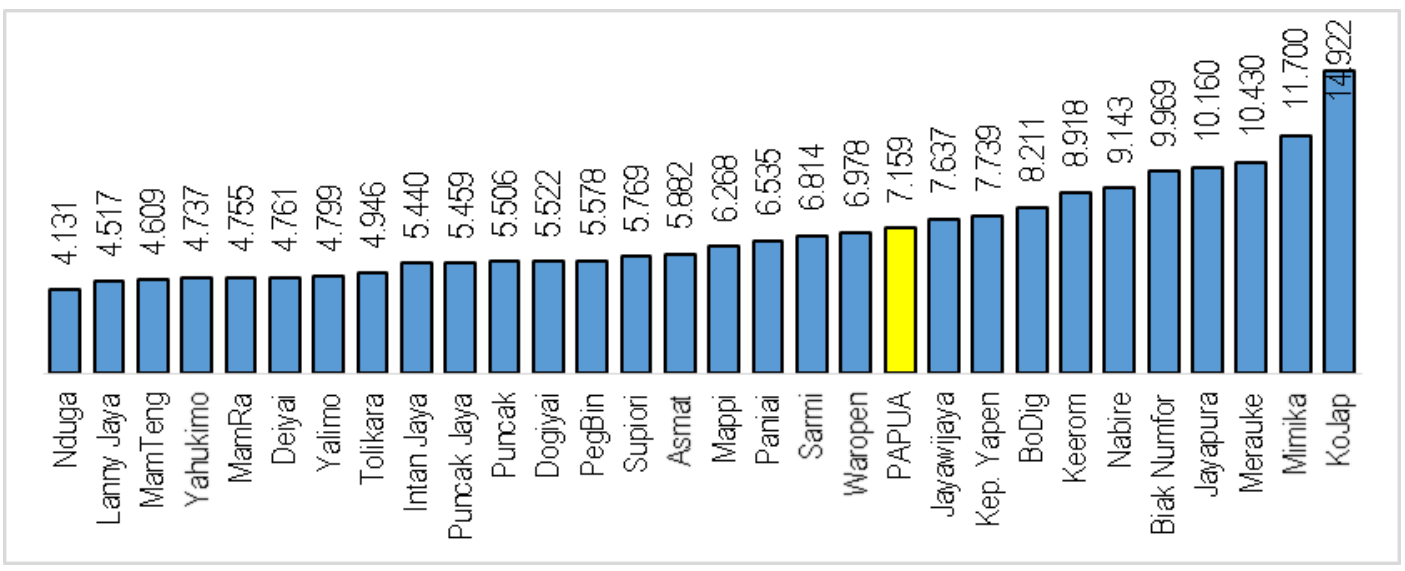

\section{Gambar 9. Pengeluaran Perkapita di Sesuaikan Kabupatan/Kota di Papua, Tahun 2018}

Sumber : BPS Papua, 2018

Gambar di atas menunjukkan pada tahun 2018 pengeluaran perkapita penduduk kabupaten/kota di Provinsi Papua sebesar Rp. 7,637 juta perkapita pertahun, pengeluaran terendah oleh penduduk di Kabupaten Nduga sebesar Rp. 4,131 juta perkapita pertahun sedangkan pengeluaran tertinggi oleh penduduk di Kota Jayapura sebesar Rp. 14,922 juta perkapita pertahun. Terdapat 10 kabupaten/kota dengan pengeluaran perkapita diatas provinsi sedangkan 19 kabupaten/kota dibawah besaran pengeluaran provinsi. Belum satupun kabupaten/kota di Papua yang besaran pengeluaran perkapitanya mendekati batas maksimum yang ditetapkan. Data di atas menunjukkan pula bahwa 10 besar kabupaten/kota 
yang memiliki pengeluaran perkapita tinggi untuk ukuran Papua merupakan kabupaten induk sedangkan kabupaten dengan pengeluaran perkapita rendah sebagian besar merupakan kabupaten hasil pemekaran (daerah otonom baru).

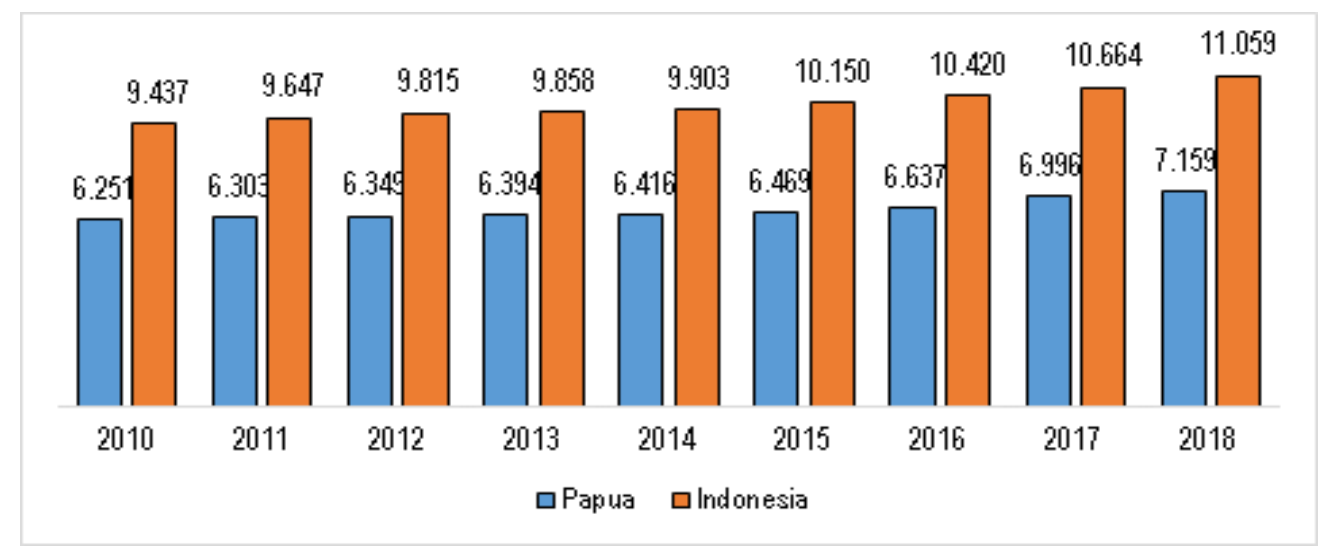

\section{Gambar 10. Pengeluaran Perkapita di Sesuaikan Indonesia dan Papua, Tahun 2010 - 2018 \\ Sumber : BPS Papua \& BPS Pusat, 2018}

Selama periode penelitian rata-rata pertumbuhan pengeluaran perkapita Papua sebesar 1,72 persen, sedangkan Indonesia mengalami pertumbuhan sebesar 2,01 persen. Pada tahun 2010 pengeluaran perkapita nasional sebesar Rp. 9,437 juta perkapita pertahun, sedangkan Papua sebesar Rp. 6,251 juta ada selisih atau gap sebesar Rp. 3,186 juta. Tahun 2018 pengeluaran perkapita disesuaikan Indonesia sebesar Rp. 11,059 juta perkapita pertahun sedangkan Papua mencapai Rp. 7,159 juta perkapita pertahun dengan selisih sebesar Rp. 3,668 juta.

\section{PENDAPATAN PERKAPITA}

Pendapatan perkapita adalah besarnya pendapatan rata-rata yang diproleh penduduk di suatu negara. Pendapatan perkapita merupakan hasil pembagian pendapatan nasional suatu negara dengan jumlah penduduk negara tersebut. Pendapatan perkapita juga merefleksikan PDB per kapita. Jika di turunkan pada tingkatan daerah (provinsi, kabupaten dan kota), maka pendapatan perkapita didapatkan dari hasil pembagian PDRB suatu daerah dengan jumlah penduduk daerah tersebut. 
Pada tahun 2018 rata-rata Pendapatan Perkapita total kabupaten/kota di Papua sebesar Rp. 37,33 juta sedangkan provinsi sebesar RP. 63,40 juta. Kabupaten/kota dengan besaran pendapatan perkapita tertinggi di Provinsi Papua adalah Kabupaten Jayapura sebesar Rp. 108,26 juta pertahun, Kota Jayapura Rp. 104,08 juta dan Kabupaten Boven Digul Rp. 66,69 juta perkapita pertahun. Kabupaten dengan besaran pendapatan perkapita terendah adalah Kabupaten Tolikara sebesar Rp. 10,25 juta, Puncak Jaya Rp. 10,03 juta dan Lanny Jaya sebesar Rp. 9,21 juta perkapita pertahun.

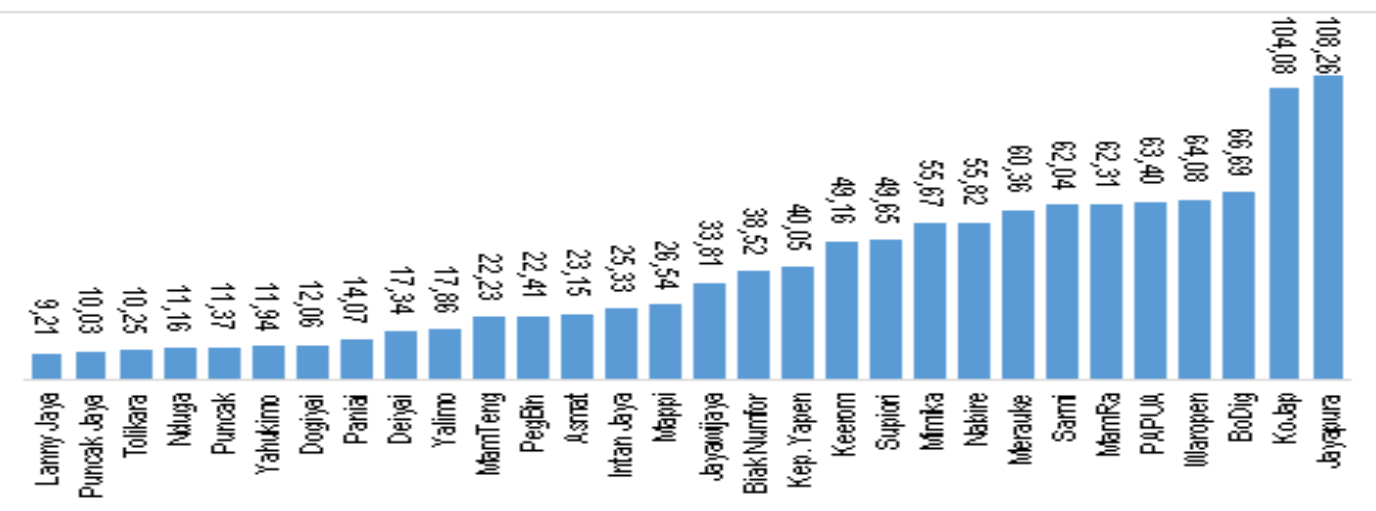

Gambar 11.Pendapatan Perkapita Kabupaten/Kota di Papua, Tahun 2018 (Juta)

Sumber : BPS Papua, 2018

Terdapat empat kabupaten/kota yang memiliki pendapatan perkapita diatas provinsi sedangkan sisanya berada dibawah besaran angka provinsi. Pada tahun 2010 pendapatan perkapita Papua sebesar Rp. 38,79 juta hingga tahun 2018 telah mencapai Rp. 63,40 juta dengan rata-rata pertumbuhan kurun waktu tersebut sebesar 9,57 persen.

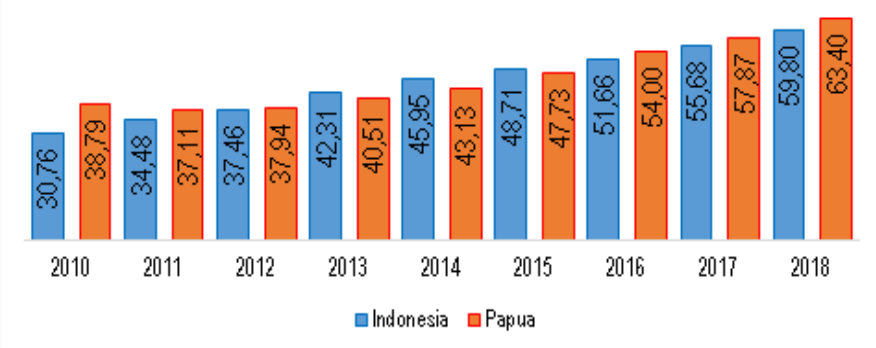

Gambar 12. Pendapatan Perkapita Indonesia dan Papua, Tahun 2010 - 2018 (Juta)

Sumber : BPS Papua \& BPS Pusat, 2018 
Data di atas juga memperlihatkan peningakatan terjadi pada angka pendapatan perkapita Indonesia namun jika dibandingkan ternyata ada kecenderungan besaran pendapatan perkapita Papua lebih tinggi dari Indonesia. Pada tahun 2010 pendapatan perkapita Indonesia sebesar Rp. 30,76 juta meningkat menjadi Rp. 59,80 juta tahun 2018, dengan pertumbuhan rata-rata sebesar 7,40 persen. Selisih antara pendapatan perkapita Indonesia dengan Papua tahun 2018 sebesar Rp. 3,60 juta.

\section{KEMISKINAN}

Publikasi BPS menunjukkan bahwa jumlah penduduk miskin di Provinsi Papua dalam kurun waktu 2010 - 2018 berfluktuasi serta cenderung mengalami penurunan. Pada tahun 2010 terdapat 981.200 jiwa penduduk miskin di Papua atau 34,10 persen dari jumlah penduduk sebanyak 2.833.381 jiwa. Pada tahun 2018 jumlah penduduk miskin di Papua berjumlah 917.630 jiwa atau 27,74 persen dari jumlah penduduk sebanyak 3.322.526 jiwa.

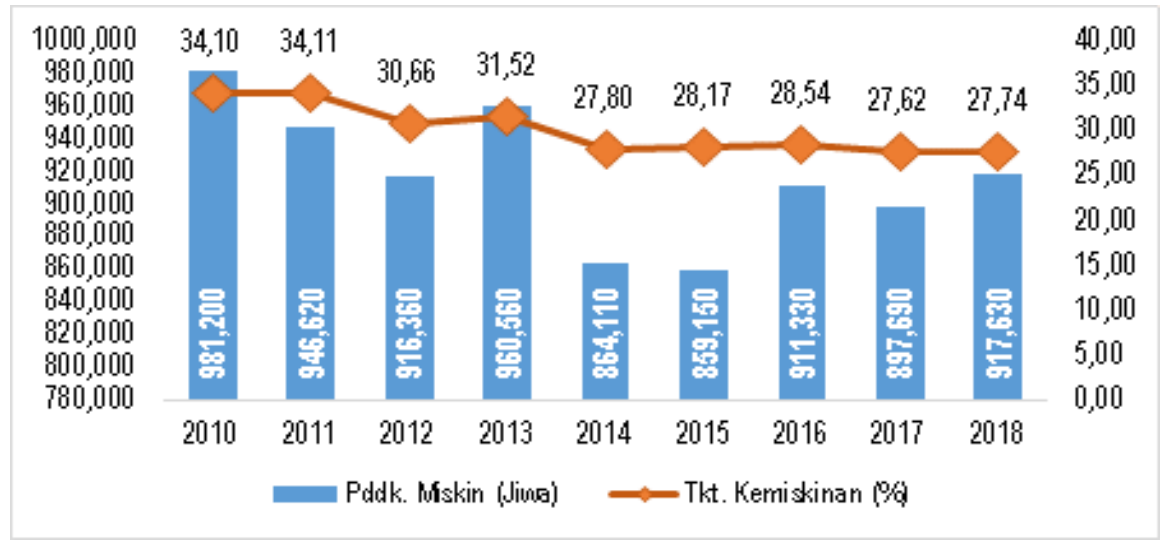

\section{Gambar 13. Penduduk Miskin dan Tingkat Kemiskinan di Papua, Tahun 2010 - 2018 \\ Sumber : BPS Papua, 2018}

Tercatat dalam laporan BPS, pada tahun 2010 terdapat 3 (tiga) kabupaten dengan populasi miskin paling tinggi antara lain Kabupaten Jayawijaya sebanyak 84.600 jiwa, Yahukimo 77.400 jiwa, dan Lanny Jaya 71.880 jiwa. Sedangkan 3 (tiga) kabupaten dengan jumlah penduduk miskin paling rendah berada di Kabupaten Sarmi sebanyak 7.100 jiwa, Supiori 7.300 jiwa dan Mamberamo Raya 7.400 jiwa. Pada tahun 2018 jumlah penduduk miskin masih terkonsentrasi di Kabupaten Jayawijaya sebanyak 82.900 jiwa, Yahukimo 
74.020 jiwa, dan Lanny Jaya 71.880 jiwa. Pada tahun 2018, kabupaten dengan jumlah penduduk miskin paling rendah berada di Sarmi sebanyak 5.670 jiwa, Supiori 7.760 jiwa dan Mamberamo Raya 6.940 jiwa.

BPS mencatat bahwa pada tahun 2018 tingkat kemiskinan yang dialami kabupaten dan kota di Papua masih cukup tinggi rata-rata sebesar 29,43 persen. Kabupaten dengan tingkat kemiskinan paling tinggi antara lain Lanny Jaya 40,10 persen, Intan Jaya 42,70 persen dan Deiyai sebesar 43,50 persen. Kabupaten dengan tingkat kemiskinan paling rendah terdapat di Kabupaten Merauke 10,50 persen, Jayapura 11,40 persen dan Kota Jayapura sebesar 13,50 persen.

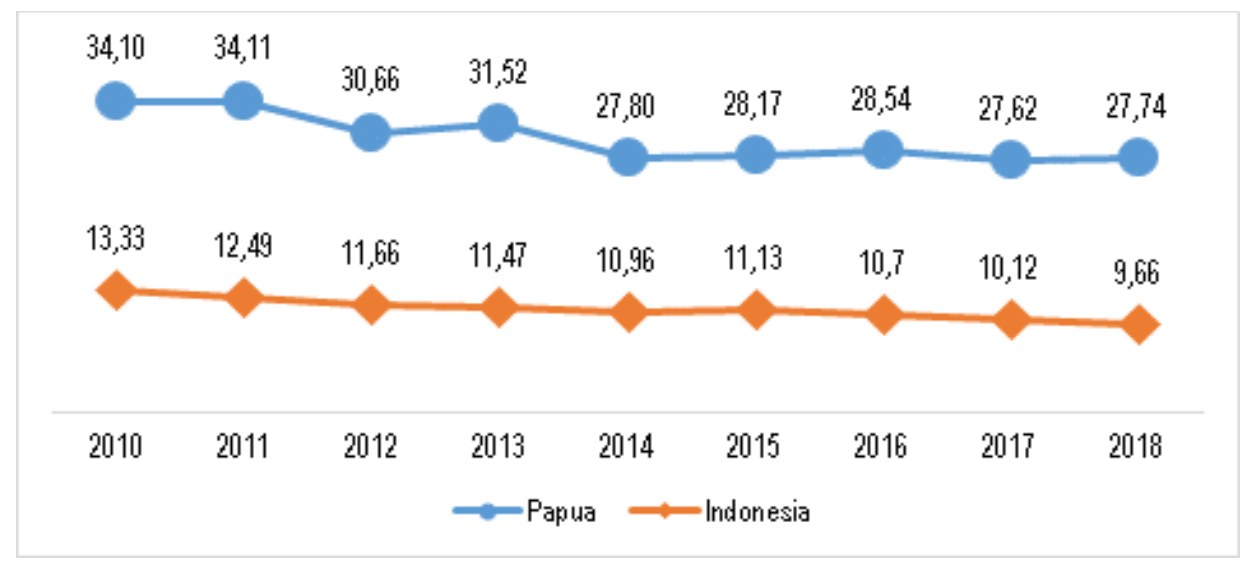

\section{Gambar 14. Tingkat Kemiskinan di Indonesia dan Papua, Tahun 2010 - 2018 (Persen) \\ Sumber : BPS Papua \& BPS Pusat, 2018}

Perbandingan tingkat kemiskinan antara Indonesia dan Papua periode 2010 - 2018 dapat kita simak secara visual dalam gambar di atas. Tingkat kemiskinan di Indonesia maupun Papua menunjukkan kecenderungan yang menurun selama periode tersebut. Tingkat kemiskinan Indonesia pada tahun 2010 sebesar 13,33 persen di Papua sebesar 34,10 persen selisinnya cukup lebar, namun pada tahun 2018 tingkat kemiskinan Indonesia sudah turun hingga mencapai 1 digit yaitu sebesar 9,66 persen, Papua juga mengalami penurunan menjadi 27,74 persen. Selama kurun waktu penelitian rata-rata tingkat kemiskinan di Indonesia sebesar 11,28 persen sedangkan di Provinsi Papua sebesar 30,03 persen atau dapat dikatakan cukup tinggi. 


\section{ANALISIS DATA}

\section{Korelasi Komponen IPM}

Dalam rangka mengetahui keeratan hubungan antara komponen pembentuk IPM dengan IPM, peneliti menggunakan tehnik analisis Korelasi Product Moment. Sedangkan data yang digunakan adalah komponen IPM : AHH, HLS, RLS, Pengeluaran Perkapita dan angka IPM kabupaten/kota di Provinsi Papua periode 2010 - 2018. Hasil analisis korelasi product moment disajikan dalam ringkasan berikut.

Tabel 1.Korelasi Komponen Pembentuk IPM dengan IPM

\begin{tabular}{|c|c|c|c|c|c|c|}
\hline \multicolumn{7}{|c|}{ Correlations } \\
\hline & & IPM & $\mathrm{AHH}$ & HLS & RLS & $\mathrm{PP}$ \\
\hline IPM & $\begin{array}{l}\text { Pearson Correlation } \\
\text { Sig. (2-tailed) } \\
N\end{array}$ & 1 & $\begin{array}{r}.642^{*} \\
.000 \\
29\end{array}$ & $\begin{array}{r}.922 \\
.000 \\
29\end{array}$ & $\begin{array}{r}.963^{\prime \prime} \\
.000 \\
29\end{array}$ & $\begin{array}{r}.871^{*} \\
.000 \\
29\end{array}$ \\
\hline $\mathrm{AHH}$ & $\begin{array}{l}\text { Pearson Correlation } \\
\text { Sig. (2-tailed) } \\
\text { N }\end{array}$ & & 1 & $\begin{array}{r}.462 \\
.012 \\
29 \\
\end{array}$ & $\begin{array}{r}.534 " \\
.003 \\
29\end{array}$ & $\begin{array}{r}.556^{\circ} \\
.002 \\
29\end{array}$ \\
\hline HLS & $\begin{array}{l}\text { Pearson Correlation } \\
\text { Sig. (2-tailed) } \\
\text { N }\end{array}$ & & & 1 & $\begin{array}{r}.870^{\circ} \\
.000 \\
29\end{array}$ & $\begin{array}{r}.702 " \\
.000 \\
29\end{array}$ \\
\hline RLS & $\begin{array}{l}\text { Pearson Correlation } \\
\text { Sig. (2-tailed) } \\
N\end{array}$ & & & & 1 & $\begin{array}{r}.859^{*} \\
.000 \\
29\end{array}$ \\
\hline PP & $\begin{array}{l}\text { Pearson Correlation } \\
\text { Sig. (2-tailed) } \\
\text { N }\end{array}$ & & & & & 1 \\
\hline
\end{tabular}

Sumber : Data diolah, 2019

Berdasarkan angka koefisien korelasi diatas terlihat bahwa seluruh komponen pembentuk IPM memiliki korelasi positif dan signifikan terhadap IPM, dengan angka koefisien korelasi berkisar antara 0,64 hingga 0,96 dan nilai Sig.(2-tailed) untuk masingmasing komponen 0,000 pada $\alpha=0,05$.

1) Koefisien korelasi antara Angka Harapan Hidup $(\mathrm{AHH})$ dengan IPM bernilai 0,64 . Besaran koefisien ini menunjukkan bahwa antara AHH dengan IPM memiliki derajat hubungan atau korelasi kuat dan positif.

2) Koefisien korelasi antara Harapan Lama Sekolah (HLS) dengan IPM sebesar 0,92. Besaran koefisien ini menunjukkan bahwa antara HLS dengan IPM memiliki derajat hubungan atau korelasi sangat kuat dan positif. 
3) Koefisien korelasi antara Rata-rata Lama Sekolah (RLS) dengan IPM sebesar 0,96. Besaran koefisien ini menunjukkan bahwa antara RLS dengan IPM memiliki derajat hubungan atau korelasi sangat kuat dan positif.

4) Koefisien korelasi antara Pengeluaran Perkapita Disesuaikan (PP) dengan IPM sebesar 0,87. Besaran koefisien ini menunjukkan bahwa antara PP dengan IPM memiliki derajat hubungan atau korelasi sangat kuat dan positif.

5) Terdapat dua komponen yang memiliki angka koefisien yang tinggi yaitu HLS dan RLS. Hal ini berarti kedua komponen tersebut dapat dikatakan sebagai pembentuk yang paling dominan terhadap IPM di Provinsi Papua, sehingga cepat lambatnya perkembangan IPM sangat tergantung kepada hasil pembangunan pada bidang pendidikan.

\section{Pengaruh IPM Terhadap Kesejahteraan Masyarakat}

Dalam mengukur pengaruh IPM terhadap kesejahteraan masyarakat atau atau kesejahteraan penduduk, digunakan data IPM sedangkan ukuran kesejahteraan dalam penelitian ini menggunakan data pendapatan perkapita dan tingkat kemiskinan Provinsi Papua. Untuk mengetahui pengaruh IPM terhadap tingkat kemiskinan dan pengaruh IPM terhadap pendapatan perkapita digunakan tehnik analisis regresi sederhana. Hasil analisis regresi sederhana diringkas dalam tabel berikut ini.

Tabel 2. Ringkasan Hasil Analisis Regresi

\begin{tabular}{|l|c|c|c|c|c|c|}
\hline \multicolumn{1}{|c|}{ Kausalitas } & Intercept & $\begin{array}{c}\text { Koefisien } \\
\text { Regresi }\end{array}$ & t-stat & Signf. & $\mathbf{R}$ & F-stat \\
\hline IPM $\rightarrow$ Pendapatan Perkapita & $-19,55$ & 5,88 & 10,633 & 0,000 & 0,97 & 113,067 \\
\hline IPM $\rightarrow$ Kemiskinan & 12,63 & $-2,28$ & $-4,403$ & 0,003 & 0,73 & 19,386 \\
\hline
\end{tabular}

Sumber : Data diolah, 2019 (terlampir)

\section{Pengaruh IPM Terhadap Pendapatan Perkapita}

Berdasarkan ringkasan hasil analisis regresi pada tabel di atas berikut akan diuraikan beberapa hal sebagai berikut :

(1) Persamaan regresi yang terbentuk : 


\section{Pendapatan Perkapita $=-19,555+5,88^{\star} \mathrm{IPM}$}

(2) Nilai intersep yang diperoleh sebesar $-19,55$; nilai tersebut menunjukkan bahwa apabila IPM tidak mengalami perubahan ( IPM = 0) maka pendapatan perkapita akan berkurang atau mengalami penurunan sebesar 19,55 persen;

(3) Nilai koefisien regresi sebesar 5,88; nilai ini menunjukkan bahwa apabila IPM meningkat sebesar 1 persen maka akan meningkatkan pendapatan perkapita sebesar 5,88 persen. Demikian pula sebaliknya apabila IPM mengalami penurunan sebesar 1 persen maka akan menurunkan pendapatan perkapita sebesar 5,88 persen (ceteris paribus);

(4) Nilai koefisien korelasi sebesar 0,97; nilai ini menunjukkan bahwa keeretan hubungan antara IPM dengan pendapatan perkapita sangat kuat dan positif.

(5) Nilai signifikansi yang diperoleh sebesar (Sig.=0,000) $<(\alpha=0,05)$, menunjukan bahwa IPM berpengaruh signifikan terhadap pendapatan perkapita.

\section{Pengaruh IPM Terhadap Kemiskinan}

Deskripsi yang dapat disampaikan berdasarkan hasil analisis regresi diatas sebagai berikut :

(1) Persamaan regresi yang terbentuk :

\section{Kemiskin $=12,63-2,28 * I P M$}

(2) Nilai intersep yang diperoleh sebesar 12,63; nilai tersebut menunjukkan bahwa apabila IPM tidak mengalami perubahan ( IPM = 0) maka tingkat kemiskin akan bertambah atau mengalami kenaikan sebesar 12,63 persen;

(3) Nilai koefisien regresi sebesar -2,28; nilai ini menunjukkan bahwa apabila IPM meningkat sebesar 1 persen maka akan menurunkan kemiskinan sebesar 2,28 persen. Demikian pula sebaliknya apabila IPM mengalami penurunan sebesar 1 persen maka akan meningkatkan kemiskinan sebesar 2,28 persen (ceteris paribus);

(4) Nilai koefisien korelasi sebesar 0,73; nilai ini menunjukkan bahwa hubungan antara IPM dengan kemiskinan sangat kuat dan positif. 
(5) Nilai signifikansi yang diperoleh sebesar (Sig.=0,003) $<(\alpha=0,05)$, menunjukan bahwa IPM berpengaruh signifikan terhadap kemiskinan.

\section{PEMBAHASAN}

Hasil analisis mengenai keeratan hubungan komponen pembentuk IPM menunjukkan bahwa semua komponen IPM memiliki hubungan yang positif dan signifikan dengan IPM. Komponen $\mathrm{AHH}$ hubungannya kuat, sedangkan komponen yang lain sangat kuat. Komponen HLS dan RLS (indeks pendidikan) memiliki besaran angka koefisien korelasi yang paling besar sehingga merupakan pembentuk IPM yang dominan dibanding $\mathrm{AHH}$ dan Pengeluaran Perkapita.

Hasil penelitian yang diperoleh memiliki relevansi dengan penelitian yang dilakukan oleh peneliti sebelumnya. Penelitian Melliana dan Zain (2013), di Jawa Timur pada 38 kabupaten/kota tahun 2010 - 2014, yaitu mengukur IPM dengan angka partisipasi sekolah (APS), jumlah sarana kesehatan, persentase RT dengan akses air bersih, tingkat partisipasi angkatan kerja (TPAK), dan PDRB perkapita. Terdapat tujuh variabel yang berpengaruh signifikan terhadap IPM antara lain variabel rasio siswa terhadap guru, APS SMP/MTs, jumlah sarana kesehatan, persentase RT dengan akses air bersih, kepadatan penduduk, TPAK, dan PDRB perkapita. Variabel yang tidak berpengaruh adalah rasio sekolah terhadap murid.

Menurut Lanjouw dalam Ginting, dkk (2008), pembangunan manusia di Indonesia identik dengan pengurangan kemiskinan. Investasi di bidang pendidikan dan kesehatan sangat berarti bagi penduduk miskin dibandingkan penduduk tidak miskin, karena modal utama penduduk miskin adalah tenaga kasar mereka. Fasilitas pendidikan dan kesehatan yang tersedia dan murah sangat membantu meningkatkan produktivitas, dan pada gilirannya meningkatkan pendapatan penduduk miskin. Dengan demikian, pembangunan manusia belum secara optimal dilakukan pemerintah dewasa ini karena hanya terfokus pada pengurangan kemiskinan. 
Hasil penelitian tentang pengaruh IPM terhadap pendapatan perkapita menunjukkan bahwa apabila IPM meningkat sebesar 1 persen maka akan meningkatkan pendapatan perkapita sebesar 5,88 persen di Provinsi Papua. Demikian pula sebaliknya apabila IPM mengalami penurunan sebesar 1 persen maka akan menurunkan pendapatan perkapita sebesar 5,88 persen (ceteris paribus). Sehingga disimpulkan bahwa IPM berpengaruh positif dan signifikan terhadap peningkatan pendapatan perkapita di Provinsi Papua. Penelitian lain yang dilakukan sebelumnya juga memberikan penjelasan yang sama, seperti Yuliatin (2016), melakukan penelitian tentang Hubungan Antara Pendapatan Perkapita dan Indeks Pembangunan Manusia di Jawa Timur 2009 - 2013. Hasil penelitian menunjukkan Pendapatan perkapita tidak berpengaruh terhadap IPM di Jawa Timur secara keseluruhan. Namun, IPM berpengaruh terhadap pendapatan perkapita secara keseluruhan.Sedangkan untuk daerah yang memiliki IPM tinggi dan menengah tidak berpengaruh atau tidak memiliki hubungan. Hal ini disebabkan oleh ketimpangan pendapatan yang berbeda-beda pada setiap wilayah dan perbedaan potensial daerah yang membuat pendapatan perkapita menjadi rendah atau bahkan bias dengan indeks pembangunan manusia untuk kabupaten di Jawa Timur pada tahun 2009 hingga 2013 (Yuliatin, 2016).

Hasil penelitian tentang pengaruh IPM terhadap kemiskinan menunjukkan bahwa apabila IPM meningkat sebesar 1 persen maka akan menurunkan kemiskinan sebesar 2,28 persen di Provinsi Papua. Demikian pula sebaliknya apabila IPM mengalami penurunan sebesar 1 persen maka akan meningkatkan kemiskinan sebesar 2,28 persen (ceteris paribus). Dengan demikian IPM berpengaruh negatif dan signifikan terhadap kemiskinan di Provinsi Papua. Hasil penelitian ini sejalan dengan beberapa penelitian yang dilakukan oleh peneliti sebelumnya. Lubis (2017), yang menemukan bahwa variabel indeks pembangunan manusia berpengaruh negatif dan tidak signifikan terhadap kemiskinan di Kabupaten/Kota Eks-Karesidenan Kedu, Banyumas dan Semarang Tahun 2010 - 2015.

Penelitian lainnya yang relevan dengan hasil temuan penelitian ini juga dilakukan oleh Waluyo, J., (2017), dengan hasil bahwa Indeks Pembangunan Manusia mempunyai pengaruh negatif dan signifikan terhadap tingkat kemiskinan di Kabupaten Muaro Jambi 
periode 2010 - 2014. Srisinto (2018), melakukan penelitian tentang Inflasi dan IPM Peranannya Terhadap Pertumbuhan Ekonomi Serta Implikasinya Pada Kemiskinan. Hasil penelitiannya menunjukkan bahwa IPM berpengaruh negatif dan tidak signifikan terhadap kemiskinan di Kabupaten Sragen Tahun 2010 - 2017.

BPSDM Papua (2013), Lambatnya capaian pembangunan manusia di Provinsi Papua ditengarai karena lambatnya capaian pembangunan pembangunan manusia pada wilayah Pegunungan Tengah Papua. Fakta ini mestinya menjadi perhatian bersama. Upaya peningkatan capaian pembangunan manusia di Papua mestinya difokuskan pada wilayah Pegunungan Tengah Papua. Identifikasi permasalahan sangat penting untuk merumuskan strategi dan program yang sesuai denga karakteristik wilayah. Selain di pegunungan tengah Papua, capaian IPM relatif rendah juga ada di sebagian wilayah selatan Papua dan beberapa kabupaten di pesisir utara Papua.

\section{SIMPULAN}

Hasil penelitian menunjukkan bahwa : (1) Semua komponen IPM memiliki hubungan yang positif dan signifikan dengan IPM. Komponen AHH hubungannya kuat, sedangkan komponen yang lain sangat kuat. Komponen HLS dan RLS (indeks pendidikan) memiliki besaran angka koefisien korelasi yang paling besar sehingga merupakan pembentuk IPM yang dominan dibanding $\mathrm{AHH}$ dan Pengeluaran Perkapita. (2) IPM berpengaruh positif dan signifikan terhadap pendapatan perkapita di Provinsi Papua. (3). IPM berpengaruh negatif dan signifikan terhadap tingkat kemiskinan di Provinsi Papua. Saran dan Rekomendasi, yang diajukan sebagai berikut : (1). Investasi dalam bidang pendidikan dan kesehatan terutama bagi penduduk miskin perlu ditingkatkan terutama dalam menyediakan fasilitas pendidikan dan kesehatan yang murah, terjangkau dan merata di seluruh wilayah terutama wilayah terpencil dan terisolir di Provinsi Papua. (2). Pemerintah perlu menjamin kelangsungan pendidikan kepada penduduk usia sekolah yang sedangkan menjalankan proses pendidikan. Meningkatkan kesadaran kolektif seluruh lapisan masyarakat tentang pentingnya pendidikan terutama pendidikan lanjutan (kejuruan) dan perguruan tinggi. (3). Pemerintah perlu meningkatkan akses penduduk terhadap pelayanan kesehatan, 
tersedianya sarana dan prasarana kesehatan secara luas dan merata, perbaikan kebutuhan gizi dan kalori, meningkatkan kualitas dan sanitasi lingkungan, dan meningkatkan kesadaran masyarakat tentang pentingnya kesehatan. (4). Keterlibatan semua komponen masyarakat dan pemerintah dalam merencanakan, melaksanakan, monitoring dan mengevaluasi program dan kegiatan serta pembiayaannya yang berkaitan dengan pembangunan manusia.

\section{DAFTAR PUSTAKA}

Baeti, N. 2013. Pengaruh Pengangguran, Pertumbuhan Ekonomi dan Pengeluaran Pemerintah terhadap Pembangunan Manusia Kabupaten/Kota Di Privinsi Jawa Tengah. EDAJ (Economics Development Analysis Journal), Vol. 2 No. 3 (2013), FE UNNES, Semarang;

BPS Indonesia, 2016, Indeks Pembangunan Manusia 2015, Badan Pusat Statistik Indonesia, Jakarta ;

BPS Indonesia, 2018, Indeks Pembangunan Manusia 2017, Badan Pusat Statistik Indonesia, Jakarta;

BPS Papua, 2018, Papua Dalam Angka 2018, BPS Papua, Jayapura;

BPSDM Papua, 2013, Pencanangan Upaya Percepatan Pembangunan Manusia Provinsi Papua, BPSDM Papua, Jayapura;

Indramawan Dendy, 2018, The Impacts Of Financial Performance Of Local Governments On Human Development Index In Papua, Simposium Nasional Keuangan Negara, Badan Pendidikan dan Pelatihan Keuangan (BPPK) Depkeu RI, Jakarta;

Lubis H. N., 2017, Analisis Pengaruh Indeks Pembangunan Manusia (IPM), Upah Dan Pengangguran Terhadap Kemiskinan Di Kabupaten/Kota Eks-Karesidenan Kedu, Banyumas, dan Semarang Tahun 2010 - 2015, Skripsi (Tidak di terbitkan), FEBI UIN Sunan Kalijaga, Yogyakarta;

Ginting, C.K.S., Lubis I., dan Mahalli K., 2008, Pembangunan Manusia di Indonesia, Jurnal Perencanaan dan Pengembangan Wilayah, Vol. 04, No. 01, Wahana Hijau

Sherraden Michael, 2006, Aset Untuk Orang Miskin : Perspektif Baru Usaha Pengentasan Kemiskinan, Raja Grafindo Persada, Jakarta;

Srisinto, 2018, Inflasi dan IPM Peranannya Terhadap Pertumbuhan Ekonomi Serta Implikasinya Pada Kemiskinan, Jurnal Litbang Sukowati, Vol. 2 No.1 (2018), Pemkab Sragen, Sragen; 
Sugiyono, 2009, Metode Penelitian Kuantitatif dan Kualitatif, Alfabeta, Bandung;

,2011, Statistika Untuk Penelitian, Alfabeta, Bandung;

2012. Metode Penelitian Kuantitatif, Kualitatif dan R \& D, Alfabeta, Bandung;

Susiyanto Didit, 2016, Konsep dan Kebijakan Pembangunan Manusia, [Online], (Tersedia: https://trimongalah.wordpress.com/2016/02/04/konsep-dan-kebijakanpembangunan-manusia/, diakses 09 Mei 2019);

United Nations Development Programme, 1990, Human Development Report 1990, UNDP,New York;

1995, Human Development Report 1995. UNDP, New York ;

Waluyo, J., 2017. Analisis Pengaruh Indeks Pembangunan Manusia (IPM), Tingkat Pengangguran dan Pertumbuhan Ekonomi Terhadap Kemiskinan di Kabupaten Muaro Jambi, Vol 5 No 3 (2016): Jurnal Perspektif Ekonomi dan Pembangunan Daerah, Universitas Jambi;

Widjojo Muridan S., dkk, 2008, Papuanisasi dan Rekonsiliasi Sosial: Model Jangka Panjang Penyelesaian Konflik di Papua, LIPI, Jakarta;

Yuliatin, 2016, Hubungan Antara Pendapatan Perkapita dan Indeks Pembangunan Manusia di Jawa Timur 2009 - 2013, Skripsi (Tidak di terbitkan), FEB UNEJ, Jember; 